NBER WORKING PAPER SERIES

THE FORMATION OF CONSUMER BRAND PREFERENCES

\author{
Bart J. Bronnenberg \\ Jean-Pierre H. Dubé \\ Working Paper 22691 \\ http://www.nber.org/papers/w22691 \\ NATIONAL BUREAU OF ECONOMIC RESEARCH \\ 1050 Massachusetts Avenue \\ Cambridge, MA 02138 \\ September 2016
}

We are grateful to Tülin Erdem, Elisabeth Honka, Carl Mela, Sridhar Moorthy, Robert Sanders, Brad Shapiro, Andrey Simonov, and Stijn Van Osselaer for comments and suggestions. The views expressed herein are those of the authors and do not necessarily reflect the views of the National Bureau of Economic Research.

NBER working papers are circulated for discussion and comment purposes. They have not been peer-reviewed or been subject to the review by the NBER Board of Directors that accompanies official NBER publications.

(C) 2016 by Bart J. Bronnenberg and Jean-Pierre H. Dubé. All rights reserved. Short sections of text, not to exceed two paragraphs, may be quoted without explicit permission provided that full credit, including $\odot$ notice, is given to the source. 
The Formation of Consumer Brand Preferences

Bart J. Bronnenberg and Jean-Pierre H. Dubé

NBER Working Paper No. 22691

September 2016

JEL No. A3,D12,D4,L0,L00,L11,L15,M31,M37,Y1,Y10,Y5,Y50

\begin{abstract}
$\underline{\text { ABSTRACT }}$
Brands and brand capital have long been theorized to play an important role in the formation of the industrial market structure of consumer goods industries. We summarize several striking empirical regularities in the concentration, magnitude and persistence of brand market shares in consumer goods categories. We then survey the theoretical and empirical literatures on the formation of brand preferences and how brand preferences contribute to our understanding of these empirical regularities. We also review the literature on how brand capital creates strategic advantages to firms that own established brands.
\end{abstract}

\author{
Bart J. Bronnenberg \\ Tilburg University and CentER \\ Warandelaan 2, Koopmans K-1003 \\ 5037 AB Tilburg \\ The Netherlands \\ bart.bronnenberg@uvt.nl \\ Jean-Pierre H. Dubé \\ University of Chicago \\ Booth School of Business \\ 5807 South Woodlawn Avenue \\ Chicago, IL 60637 \\ and NBER \\ jdube@chicagobooth.edu
}




\title{
The Formation of Consumer Brand Preferences*
}

\author{
Bart J. Bronnenberg, CentER Tilburg and CEPR \\ Jean-Pierre Dubé, Chicago Booth and NBER
}

September 21, 2016

\begin{abstract}
Brands and brand capital have long been theorized to play an important role in the formation of the industrial market structure of consumer goods industries. We summarize several striking empirical regularities in the concentration, magnitude and persistence of brand market shares in consumer goods categories. We then survey the theoretical and empirical literatures on the formation of brand preferences and how brand preferences contribute to our understanding of these empirical regularities. We also review the literature on how brand capital creates strategic advantages to firms that own established brands.
\end{abstract}

JEL: L11, L15, M31, M37

\section{INTRODUCTION}

The economics literature has long recognized the importance of consumer brands in the formation of the industrial market structure of consumer goods industries. Braithwaite described the rapid growth in the number of consumer brands during the early twentieth century as follows:

${ }^{*}$ We are grateful to Tülin Erdem, Elisabeth Honka, Carl Mela, Sridhar Moorthy, Robert Sanders, Brad Shapiro, Andrey Simonov, and Stijn Van Osselaer for comments and suggestions. E-mail addresses: bart.bronnenberg@tilburguniversity.edu,jdube@chicagobooth.edu. 
A growing number of goods which were formerly sold in bulk are now sold as branded goods and are advertised nationally. Tobacco, groceries, drugs, sweets, paint are a few of the more obvious examples. Such commodities can be put in distinctive packages, branded and labelled in such a way that their individuality can easily be established. With goods sold by the yard or ready-made clothes this is less easily accomplished, but even with such things producers are now attempting to make their brand or trade mark a distinctive feature of the commodity. By these means they are able to tie up their advertising with their own products, and to ensure that, when they incur advertisement costs, the increased demand will be directed, not to the commodity as a whole, but to their particular make of the commodity. Thus they are able to secure for themselves, if their advertising is successful, a partial monopoly based on reputation which it is not possible to secure when goods are sold in bulk. (Braithwaite, 1928)

Bain (1956) argued that "the advantage to established sellers accruing from buyer preferences for their products as opposed to potential-entrant products is on the average larger and more frequent in occurrence at large values than any other barrier to entry." In the latter part of the twentieth century, the degree of concentration in consumers goods industries grew at a much faster pace than other industries in the US (Caves and Porter, 1980). By the end of the twentieth century, most consumer goods industries were dominated by a small number of brands commanding most of the share of sales (Bronnenberg, Dhar, and Dubé, 2007). Most striking, many of the dominant consumer brands in 1923 were still the dominant brands in their respective categories in 1983 more than half a century later ${ }^{1}$, although the findings are predominantly in food categories. ${ }^{2}$

Surprisingly, consumers are routinely found to be unable to distinguish between leading national brands in blind taste tests (Husband and Godfrey, 1934; Thumin, 1962; Allison and Uhl, 1964, p. 336) in spite of self-reported strong preferences for specific national brands. In the famous "Pepsi Challenge" promotional campaign during the 1970s, subjects exhibited a more than $50 \%$ chance of choosing Pepsi over Coca Cola, ${ }^{3}$ even though Coca Cola was the dominant cola brand and one of the world's most valuable consumer brands at the time. ${ }^{4}$

\footnotetext{
${ }^{1}$ Advertising Age (1983), "Study: Majority of 25 Leaders in 1923 Still On Top" (September 19), 32.

${ }^{2}$ Golder (2000) later showed that these results were obtained by a selective focus predominantly on food industries, and that the findings weaken when extended to the databases full set of 100 consumer goods categories.

${ }^{3} \mathrm{http}: / / w w w . b u s i n e s s i n s i d e r . c o m / p e p s i-c h a l l e n g e-b u s i n e s s-i n s i d e r-2013-5$

${ }^{4}$ Coca-Cola continued to dominate consumer brands, listed as the world's second most valuable brand in 1993
} 
In this article, we review the literature studying the formation of consumers' brand preferences. Our goals consist of summarizing several stylized facts regarding brands and the industrial market structure of consumers goods industries, and surveying the theoretical and empirical analyses of different mechanisms through which consumers develop a brand preference. The practice of branding spans a wide array of products, ranging from physical goods to services and even events, and a wide array of buyer contexts, ranging from households to enterprises. However, we will focus most of our discussion on consumer preferences for physical consumer goods, and in particular for non-durables sold in supermarket, drug, convenience and mass-merchandise retail store formats.

Our review is structured as follows. In section 2, we begin with a brief overview of consumer brands and their marketing function. We then use a new and very large database summarizing the sales and marketing of consumer brands to replicate several empirical regularities in the market structure of branded consumer goods industries. Many branded consumer goods industries exhibit substantial geographic dispersion in market shares. This dispersion is found to be persistent, in some cases over more than a century, and may tie back to the original order of entry among the current surviving brands. At the individual consumer level, brand tastes are also found to be highly persistent and to evolve slowly over a consumer's lifetime.

In section 3, we review various mechanisms that potentially contribute to the persistence in brand tastes and the persistence in brand market structure. On the demand side, there is a longstanding literature studying brand choice inertia and brand loyalty as a psychological switching cost. However, the empirical magnitudes of estimated loyalty are typically insufficient to explain the persistence in brand market shares across decades. A separate literature has discussed the role of consumer knowledge and brand information in brand choices. Our discussion of this literature distinguishes between knowledge about search characteristics, or brand attributes that can be determined prior to purchase, and experiential characteristics, or brand attributes that are only learned after purchase and consumption. Empirically, consumers have limited information about both search and experiential characteristics. Empirical estimates of search costs associated with gathering search attributes are typically found to be high and, accordingly, consumers may only (according to Financial World) and the most valuable brand from 2000 to 2013 according to Interbrand. See http://www.bloomberg.com/news/articles/2013-10-03/the-most-valuable-brands-in-america-2000-to-2013. 
consider a small subset of the available variety when making purchases. The literature has been mixed regarding the rate at which consumers learn about experiential characteristics through purchase and consumption. The evidence suggests that information barriers could create persistent advantages to established brands.

On the supply side, firms' incentives may not favor the endogenous supply of information in equilibrium, even when brand information disclosure is costless. In fact, in some settings, firms may endogenously seek to obfuscate information through measures that increase consumers' search costs. These supply-side incentives would likely exacerbate consumers' lack of information, sustaining the advantages of familiar and established brands. Firms with established brands may also be able to leverage consumers' brand familiarity to create advantages in new product launches that extend the established brand's name.To keep the article focused, this review does not cover the extensive research on consumer brand perceptions from the psychology perspective. For a recent overview of that literature, see, for instance, Muthukrishnan (2015) or Schmitt (2012).

In section 4, we discuss the proliferation of brands and various underlying factors that may influence the overall supply of brand variety. We also discuss how firms with established brands and brand capital may have an advantage when launching new products that extend an existing brand name into new markets. Empirically, many of the new consumer product variants launched later in the twentieth century were extensions of established brands. Section 5 concludes.

\section{CONSUMER BRANDS AND MARKET STRUCTURE}

In this section, we define the concept of a consumer brand and discuss several stylized facts regarding the market structure of consumer packaged goods (CPG) brands in the US. CPG categories consist of consumable goods like food, drinks, household cleaning products, health and beauty products. These goods are typically replaced at a regular frequency in contrast with durables, like automobiles and furniture. The CPG sector provides a useful case study of consumer brands. The industry is very large, with annual revenues reaching $\$ 8$ trillion globally ${ }^{5}$ and $\$ 2.1$ trillion in the $\mathrm{US}^{6}$

\footnotetext{
${ }^{5}$ According to McKinsey: http://www.mckinsey.com/industries/consumer-packaged-goods/our-insights/threemyths-about-growth-in-consumer-packaged-goods

${ }^{6}$ According to the Grocery Manufacturer's Association: http://www.gmaonline.org/about
} 


\subsection{What is a brand?}

The term "brand" "derives from the Old Norse 'brandr' meaning 'to burn." The use of the term evolved in Middle English to the practice of "marking permanently with a hot iron," a practice used for the marking of cattle and livestock. ${ }^{8}$ The practice of branding consumer goods with a name or logo is however much older and has been part of economic exchange since the invention of papyrus in early Egypt and of paper in the Western Zhou Dynasty of China needed to make posting signs (Landa, 2006). The identity of the brand differentiated the product from others of the same category and enabled buyers to appraise its origins and value before buying. Recovered from the ruins of Pompeii, preserved loafs of bread carried markings, made with so-called bread stamps, to signify the origin of its maker and its quality, providing a demonstration of the use of branding as early as AD 79. ${ }^{9}$ The branding of bread was also used in medieval Europe to enforce regulation of its quality.

In 1931, the American Marketing Association formally defined a brand as a "word, letter, group of words or letters composing a name, a design, or a combination of these which identifies the goods or services of one seller or group of sellers and/or distinguishes them from those of competitors" (Committee on Definitions, 1935). But a brand is more than the product it identifies "because it can have dimensions that differentiate it in some way from other products designed to satisfy the same need. These differences may be rational and tangible - related to product performance of the brand - or more symbolic, emotional, and intangible - related to what the brand represents." (Keller, 2012)

The practice of branding goods using a name, logo, or marking, is ubiquitous in many industries, most prominently in the CPG industry, but also in the consumer apparel industry and the consumer electronic goods industry. The market for branded CPG goods still grows, even in western economies (Hirose, Maia, Martinez, and Thiel, 2015). In many emerging markets, currently modernizing their retail formats and distribution infrastructures, demand for branded retailed goods is just taking off (Bronnenberg and Ellickson, 2015).

In addition to their ubiquity, brands are estimated to be highly valuable assets. According to

\footnotetext{
${ }^{7}$ https://en.wikipedia.org/wiki/Brand

${ }^{8} \mathrm{https}: / / \mathrm{www} \cdot$ google.com/?ion=1\&espv=2\#q=origin\%20of\%20word\%20brand

${ }^{9}$ see http://www.creativebloq.com/branding/milestones-history-branding-91516855
} 
industry expert Interbrand, the top 100 most valuable global brands represented a joint value in excess of $\$ 1.7$ trillion in 2015. Of these, CPG brands represent 21 of the world's 100 most valuable brands, with a combined value of $\$ 259$ billion. ${ }^{10}$ The "brand value" or commercial value of a brand's underlying trademark to the firm that owns the mark can be a large and important intangible asset. While it is widely believed that brands create important barriers to entry and help sustain supranormal profits (e.g. Bain 1956; Demsetz 1982; Schmalensee 1982a, 1983), the measurement of brand value is challenging in practice. The commercial value to a firm of owning the trademark to a brand is ultimately defined relative to a counterfactual (Goldfarb, Lu, and Moorthy, 2008): what are the net present value of a firm's factual equilibrium profits versus what would have been the firm's net present value of equilibrium profits but-for the brand? Borkovsky, Goldfarb, Haviv, and Moorthy (2016) develop an equilibrium framework with which to evaluate this counterfactual in the context of a dynamic oligopoly with firms competing on both prices and advertising investments into brand goodwill stocks. A limitation in these model-based approaches is that they infer the "brand equity"11 using a residual approach ${ }^{12}$ that loads all the unexplained variation in consumer brand choices (i.e. net of observed prices and marketing variables) into an all-encompassing brand intercept. Since this intercept will also account for unobserved (to the researcher) characteristics of the product, it may over-state the actual brand equity.

\subsection{Brands and Geography}

Previous work has documented the large differences in the industrial structure of consumer goods industries across countries (Adams, 2006; Sutton, 1991). However, there has been a long debate in the marketing literature regarding the potential differences within a large country like the United States. The marketing literature has routinely used the term "national brand" to refer to widelydistributed manufacturer's or producer's brands. The use of this term has been discouraged at least since 1935, unless the brand "is used in advertising and selling over a considerable portion of the country irrespective of the nature of its sponsorship" (Committee on Definitions, 1935). However, the term national brand may even be misleading for a brand with national distribution.

\footnotetext{
${ }^{10}$ See Interbrand's 2015 ranking: http://interbrand.com/best-brands/best-global-brands/2015/ranking/

${ }^{11}$ Brand equity refers to the incremental utility a consumer obtains from a product from the "brand identity."

${ }^{12}$ This residual approach has been used at least since Srinivasan (1979).
} 
According to Coutant (1934): "There is no such thing as a national market" and that while "certain groups of these cities have similar characteristics...it is fallacious to regard them altogether as a unified big city market." Coutant (1934) relied on anecdotal evidence for regional differences in the preferences and perceptions of given brands.

Bronnenberg, Dhar, and Dubé $(2007,2011)$ provide a detailed description of the geographic patterns in CPG brand shares across the US using a large, longitudinal Nielsen database spanning the top two brands in each of 31 food categories for the 39 months between 1993 and 1995. The categories are highly concentrated, with an average 1-firm concentration ratio of $41 \%$ within a geographic area. For the average category studied, they also find that $92 \%$ of the pooled variation in market shares across time, markets, and brands is explained by the interaction of persistent market and brand effects, with no category under 63\%. Consistent with other work (e.g., Bronnenberg and Mahajan, 2001), they find spatial covariance in the market shares; but most categories exhibit geographic independence after about 500 miles. The geographic variance has several striking features. Bronnenberg, Dhar, and Dubé (2007) find considerable regional dispersion in the identity of the "brand leader" within a category. They also find that the market shares and brand leadership positions are persistent over the three-year span of the data.

We now extend the findings in Bronnenberg, Dhar, and Dubé (2007) to the entire US CPG industry. We use the Nielsen-Booth extracts of the Nielsen Retail Measurement System (RMS) data available from the Kilts Center for Marketing at the University of Chicago Booth School of Business. The data span about 35,000 stores with formats including supermarket, drug, mass and convenience located across 76 Scantrack markets. ${ }^{13}$ The data track weekly retail sales and prices at the level of the individual Universal Product Code (UPC) and span 1,088 product categories (designated by Nielsen's module codes) from 2006 to 2014. These categories span 10 broad departments: Alcoholic Beverages, Dairy, Deli, Dry Grocery, Fresh Produce, Frozen Foods, General Merchandise, Health \& Beauty, Non-Food Grocery, and Packaged Meat. While these categories exclude non-grocery consumer goods such as electronics and apparel, the RMS database collectively represents almost 2 trillion US dollars in sales over the markets and time periods covered. We collapse the data to the brand, market and month level, yielding 231,580 unique brands and 108 months. For each of the categories, we then retain the top two brands based on overall national

\footnotetext{
${ }^{13} \mathrm{~A}$ Nielsen Scantrack definition corresponds approximately to a large metropolitan area.
} 
dollar sales. ${ }^{14}$ Table 1 summarizes the data used for our analysis.

In general, the sales in these CPG product categories are very concentrated, as summarized in Table 2. On average across categories and Scantrack markets, the top brand commands $46 \%$ of equivalent unit sales, which is consistent with the analysis of food categories in Bronnenberg, Dhar, and Dubé (2011). The average four-firm concentration ratio is $79 \%$. The 25th percentile $\mathrm{C} 1$ is almost $30 \%$ and the 25 th percentile $\mathrm{C} 4$ is $66 \%$. Although not reported in the tables, there is little systematic difference in the concentration patterns across the 10 departments. Only Alcoholic Beverages stands out with an average $\mathrm{C} 1$ and $\mathrm{C} 4$ of only $40 \%$ and $71 \%$ respectively.

In Table 3, we report the results of an analysis of variance that pools the top two national brands in each of 1,069 categories across the 108 months and 76 geographic markets. We decompose the brand shares into market, brand and month fixed-effects, along with an interaction between market and brand. Table 3 reports the R-square for each of these components. Our findings broadly replicate the analysis of food categories in Bronnenberg, Dhar, and Dubé (2007). We do find larger time effects than Bronnenberg, Dhar, and Dubé (2007), on average explaining $11 \%$ of the variance in a category's shares. However, market and brand effects are much larger on average than these time effects. Moreover, the interaction between market and brand explains $68 \%$ of the variance on average, and is much larger than the sum of the individual brand and market components.

In Table 4, we report the average R-square values across all the categories within a department. With the exception of Fresh Produce, we observe that the main effect of brands is smaller and that of markets is larger for the food and beverage categories than for non-food categories like General Merchandise and Health \& Beauty. The relatively small role of brand effects confirms the contentious notion of a "national brand," at least in food categories. Interestingly, the non-food categories also have much higher time effects that explain almost $20 \%$ of the share variance. In contrast, time explains under $10 \%$ of the share variation in the food categories, except for Fresh Produce. These findings suggest that the persistence in market structures and the differences in market shares of individual brands across regions of the US may be more pronounced in food categories than in non-food categories.

Pooling all the top-selling national brands in each of the categories, the average geographic

\footnotetext{
${ }^{14}$ For 19 of these categories there is only one brand available in a given geographic market. Therefore table 3 reports on 1,069 categories.
} 
range in market shares is 41 percentage points. Hence, a brand commanding a $50 \%$ share in one US city might only have a $9 \%$ share in another US city. If we focus on food departments, the average range is well over $50 \%$. We also observe variation in the identity of the market leader. The top-selling national brand dominates $82 \%$ of the geographic markets, on average.

\subsection{Persistence in Market Shares}

The small time effects documented in Bronnenberg, Dhar, and Dubé (2007) and generalized in section 2.2 above are suggestive of persistence in brand shares within a market. Previous work has documented persistence in market shares over horizons typically spanning less than a decade. In a meta-analysis of 44 studies that apply univariate time-series models to 213 brand share series, Dekimpe and Hanssens (1995) find that almost all the studied series exhibit market share stationarity.

A growing body of evidence suggests the persistence in brand market shares spans much more than a decade. A survey-based study in the business press found that for 25 large consumer products categories, 20 of the top brands in 1923 were still dominant in 1983, more than half a century later. ${ }^{15}$ All 25 brands were still ranked among the top 5 in the category in 1983. Golder (2000) extended this analysis to 100 categories and using more reliable 1997 market share data. He finds that only $23 \%$ of the dominant firms in 1923 remain dominant in 1997; although nearly 50\% remain in the top 5. The national data used in these studies might mask some of the important regional differences in market shares and leadership positions summarized in section 2.2 above.

Unlike this previous work, Bronnenberg, Dubé, and Gentzkow (2012) account for geographic differences in market shares across US regions and find much stronger evidence of longer-term persistence in market shares. They study the long-term persistence in CPG market shares across geographic areas in the US using Nielsen's Homescan Panel. They combine these data with the Consolidated Consumer Analysis (CCA) database compiled by aggregating consumer surveys conducted by newspapers nationwide from 1948 to 1968. For 27 CPG product categories, the authors observe the market shares for the top two brands by geographic region for 2006-2008 and for 1948-1968. A pooled regression of the historic share level on the current share level fails to reject an intercept of zero and slope of one. The magnitudes of the point estimates lead the authors to

\footnotetext{
${ }^{15}$ Advertising Age (1983), "Study: Majority of 25 Leaders in 1923 Still On Top" (September 19), 32.
} 
conclude "that the best predictor of a past purchase share given the data we observe is the present purchase share."

The empirical literature on pioneering advantage also documents persistence in brand market shares, albeit with a focus on the persistence of dominance dating back to the initial entrants into a new product category. Early work found strong evidence of a persistent market share advantage for first entrants (Robinson and Fornell 1985; Urban, Carter, Gaskin, and Mucha 1986; Lambkin 1988; Robinson 1988; Parry and Bass 1990; Kerin, Varadarajan, and Peterson 1992; Brown and Lattin 1994). A similar persistence of dominance dating back to 1933 is reported for consumer brands in the UK (Keller 2012, p. 21). Kalyanaram, Robinson, and Urban (1995) provide a thorough survey of the literature along with empirical generalizations regarding the negative correlation between historic order of entry and current market share. The evidence for pioneering advantage on market shares has been under debate. Some of the debate has revolved around the accuracy of the definition of a market pioneer (Golder and Tellis, 1993). The key consistent finding is the persistence in market shares and the advantages to early movers (even if not for the first entrant) that "survive" long-term.

On the econometric side, a potentially serious concern with the interpretation of these sources of persistence regards the econometric identification of an early-mover effect. The literature has typically relied on pure time-series analysis. ${ }^{16}$ These data cannot empirically distinguish between state dependence (the "early-mover" effect) and the plausible heterogeneity between firms and their brands. For instance, if market pioneers systematically exhibit greater managerial skill or launch better brands/products, this heterogeneity could spuriously identify a pioneering advantage effect.

Bronnenberg, Dhar, and Dubé (2009) resolve this econometric problem by pooling withinmarket time-series data for the 50 largest Nielsen Scantrack markets. Like Golder and Tellis (1993), they obtain their historic roll-out information through an extensive search of historic documents and archives. They assemble six CPG category case studies for which they observe 39 months of monthly market share data for the leading national brands in each of the 50 markets. These data are matched with the exact year during which each of these leading brands entered each

\footnotetext{
${ }^{16}$ One exception is (Brown and Lattin, 1994) who use a cross-section of markets with no within-market variation. Unfortunately, in their data the first entrant is the same in 37 of the 40 studied markets.
} 
of the 50 markets. Their key identifying assumption is that the timing of entry into each market is exogenous. Most of the brands studied originated during the late 1800s, long before marketing and distributional technology existed to coordinate a national launch.

For the six categories studied, Bronnenberg, Dhar, and Dubé (2009) find that the historic orderof-entry (often a century earlier) amongst survivor brands in a geographic market predicts the current rank-order of market shares in that market. These findings are visualized in Figure 1 which plots the geographic distribution of brand shares for the Ground Coffee category across US cities. The diameter of each circle is proportional to a brand's market share in that city, and shading indicates the earlier entrant. Historic order-of-entry in a geographic market also predicts the current rank order of brands' perceived quality levels as measured by Young \& Rubicam's 2004 Brand Asset Valuator survey. For 49 of the top two national brands in 34 CPG categories, Bronnenberg, Dhar, and Dubé (2009) are able to identify the city-of-origin (although not the complete roll-out history). They find a strong correlation between a brand's share in a given market and the Euclidean distance to its market of origin. In particular, a brand's share is on average 20 percentage points higher in the market of origin than in a distant market more than 2,500 miles away. This finding is consistent with the historic diffusion of brands launched in the late 19th and early 20th centuries with entry in more distant markets occurring relatively later. ${ }^{17}$

In summary, the current market structure of CPG brands in terms of their market shares is highly persistent over a horizon spanning at least half a century. Moreover, the historic roll-out patterns for brands seem to be associated with the observed share levels amongst surviving market leaders today, even in categories for which roll-out began during the late 19th century.

\section{PERSISTENCE IN BRAND PREFERENCES}

\subsection{Overview}

Many factors might potentially explain the persistent differences in the market shares across markets and the order-of-entry effects discussed in section 2.3. On the supply side, Bronnenberg, Dhar, and Dubé (2009) explore a number of potential mechanisms including location of plants and

\footnotetext{
${ }^{17}$ See for instance (Bartels, 1976; Tedlow, 1990) for detailed discussions of how entrepreneurs in the late 19th century with new consumer brands gradually rolled them out across the US.
} 
even potential relationships with retailers. However, none of these factors were found to explain much of the geographic component in brand shares. We now explore theories of the formation of consumer brand preferences and empirical evidence that might help understand the underlying mechanisms contributing to the observed persistence.

On the demand side, consumer psychologists have studied how a consumer develops a brand preference through positive associations between the brand and the consumption benefits of the underlying product. Such associative learning could arise, for instance, through signals whereby the consumer learns that the brand predicts a positive consumption experience. Alternatively, under evaluative conditioning, the consumer forms a positive preference for a brand through repeated cooccurrences with positive stimuli, like good mood (affect) or a popular celebrity. In the same vein, a consumer may learn about a brand through her memory of positive experiences with similar products. We refer the interested reader to Van Osselaer (2008) for a survey of the consumer psychology literature on consumer learning processes.

Most of the literature surveyed herein treats the consumer's perceived value of a brand as a product characteristic. As the perception of the brand changes, the consumer's expected utility for the branded product changes accordingly. In contrast, Becker and Murphy (1993) theorized that brands and marketing activities related to branding constitute consumption goods that are complementary to the consumption of the physical good being branded. In this regard, the consumption benefit of the brand enhances the consumption benefit of the good and vice versa. A limited set of empirical studies has attempted to test this paradigm directly. To the best of our knowledge, Kamenica, Naclerio, and Malani (2013) provide the only direct evidence. ${ }^{18}$ They conduct randomized clinical trials to test whether the treatment effect of direct-to-consumer advertising has a causal effect on a subject's physiological reaction to a drug. In particular, a branded antihistamine was found to be more effective when subjects were exposed to that brand's advertising as opposed to a competitor brand's advertising. This complementarity offers one explanation for the inconsistencies in laboratory studies of consumer preferences in conditions where brands are removed (blind taste tests) versus conditions with brand labels are present (e.g. Allison and Uhl, 1964).

\footnotetext{
${ }^{18}$ An indirect test of Becker and Murphy (1993)'s theory exploits the Slutsky symmetry condition by testing whether a shift in demand for the physical good increases the consumption of the brand's advertising. Tuchman, Nair, and Gardete (2015) use data that match household-level time-shifted television viewing on digital video recorders with in-store shopping behavior. They find that in-store promotions that increase a household's consumption of a brand cause an increase in the household's propensity to watch (i.e. not skip) that same brand's commercials.
} 
To formalize our discussion of the empirical literature, consider the following model of the conditional indirect utility for a consumer choosing brand $j$ from among $J$ alternatives at time $t$ :

$$
u_{j t}=\mu_{j}\left(X_{t} ; \alpha\right)+F_{j}\left(H_{t} ; \gamma\right), j=1, \ldots, J
$$

where $\mu_{j}\left(X_{t} ; \alpha\right)$ is the relevant function to brand $j$ of the products' characteristics including current marketing conditions like the prices, $X_{t} . F_{j}\left(H_{t} ; \gamma\right)$ is the relevant function to brand $j$ of a household's shopping history (or past "brand experiences), summarized in the state vector $H_{t}$. Finally, $\Theta=(\alpha, \gamma)^{\prime}$ are structural parameters ("tastes"). In the discussion that follows, it will be helpful to distinguish between the role of current marketing and product characteristics, $\mu_{j}\left(X_{t}\right)$, and the consumer's purchase history and past experiences, $F_{j}\left(H_{t}\right)$. In extremis, one might assume that all that matters are the initial brand influences a consumer experiences during childhood, in which case $\mu_{j}\left(X_{t}\right)=0$. Alternatively, one might assume that all that matters are the current marketing conditions, in which case $F_{j}\left(H_{t}\right)=0$.

Theorists have analyzed various mechanisms through which current willingness to pay for brands reflects past brand experiences. The function $F_{j}\left(H_{t}\right)$ acts like a "brand capital stock" which could stem from various sources including habit formation (e.g. Pollak 1970; Becker and Murphy 1988), switching costs (e.g. Farrell and Klemperer, 2007), advertising and branding goodwill (e.g. (Doraszelski and Markovich, 2007; Schmalensee, 1983)), evolving quality beliefs through learning (Schmalensee, 1982a) and peer influence (e.g. Ellison and Fudenberg, 1995). The function $\mu_{j}\left(X_{t}\right)$ captures current marketing conditions that could include prices, in-store promotions like discounts and displays, advertising and even shelf space allocation. ${ }^{19}$ Our discussion below focuses mostly on sources of brand capital stock.

\subsection{Persistent Brand Preferences Over a Consumer's Lifetime}

Lenin is attributed with the quotation: "Give me four years to teach the children and the seed I have sown will never be uprooted" (Albig, 1939). This strong view is shared by some of the literature

\footnotetext{
${ }^{19}$ The findings for an effect of shelf-space on consumer attention to brand and purchase have been mixed, with small effects documented in the field experiments in Drèze, Hoch, and Purk (1994) and much larger effects in the eye-tracking experiments in Chandon, Hutchinson, Bradlow, and Young (2009). Similarly, Ataman, Mela, and Heerde (2008) find that the success of a newly launched brand into an existing CPG category is highly correlated with the breadth of its distribution.
} 
on consumer brand preferences: "[i]f Tide laundry detergent is the family favorite, this preference is easily passed on to the next generation. The same can be said for brands of toothpaste, running shoes, golf clubs, preferred restaurants, and favorite stores" (Berkman, Lindquist, and Sirgy, 1997, pp. 422-3). Returning to our model in equation (1), under this view, a consumer's preferences are entirely driven by $F_{j}\left(H_{0}\right)$ where $H_{0}$ represents her initial experiences in life, including how her parents shopped.

Guest (1955) documented early evidence that brand preferences develop early in a child's life and persist into adulthood. He conducted a brand preference survey for 813 school children in early 1941 and was able to repeat the survey for $20 \%$ of the original respondents twelve years later, in the spring of 1953. Across 16 product categories, he found a 39\% rate of agreement between the stated preferred brands in the two waves. A subsequent survey in 1961 of the same $20 \%$ of the original respondents generated a rate of agreement of $26 \%$ (Guest, 1964). The evidence is suggestive that events early in a consumer's lifetime may have lasting effects. However, "obviously, one cannot simply assume that what is learned during childhood somehow 'transfers intact' to adult life" (Ward, 1974).

The literature on consumer socialization research has studied mechanisms through which adult brand preferences are formed early in life during childhood (Moschis and Moore, 1979) especially through intergenerational transfer and parental influence (Ward, 1974; Moschis, 1985; Carlson, Grossbart, and Walsh, 1990; Childers and Rao, 1992; Moore, Wilkie, and Lutz, 2002) and peer influence (Reisman and Roseborough, 1955; Peter and Olson, 1996). Anderson, Kellogg, Langer, and Sallee (2015) document a strong correlation in the automobile brand preferences of parents and their adult children. Sudhir and Tewari (2015) use a twenty-year survey panel of individual Chinese consumers and find that growing up in a region that experienced rapid economic growth during one's adolescence is correlated with consumption of non-traditional "aspirational" goods and brands during adulthood. ${ }^{20}$ Returning to our model in equation (1), this evidence suggests that a consumer's preferences at a given moment in time will reflect a combination of her current influences including family, peers and local marketing, $\mu_{j}\left(X_{t}\right)$, as well as her past brand purchases and experiences, $F_{j}\left(H_{t}\right)$.

With the exception of the surveys used in, e.g., Guest (1955) and Sudhir and Tewari (2015),

\footnotetext{
${ }^{20}$ These aspirational goods consist primarily of western brands consumed socially.
} 
researchers typically do not have access to individual-level brand choice histories that span a consumer's lifetime. Bronnenberg, Dubé, and Gentzkow (2012) exploit the geographic heterogeneity in brand popularity as discussed in section 2.2 above. They match the Nielsen-Kilts Homescan CPG purchase panel data with a Panelviews survey of the same households. From the survey, they can determine the primary shopper's state of birth, state of current residence, age of move and current age for nearly 40,000 US households. They then test whether and the extent to which a household's current shopping behavior is associated with her state of birth. Variation in the current age of a consumer and the historic timing of her move creates variation in how much time a consumer spent in her birth state and current state. Accordingly, they observe how quickly a consumer's brand preferences converge towards those of the typical non-migrant in the current state of residence. The authors study an individual's purchase shares for the two top brands across 238 product categories.

Bronnenberg, Dubé, and Gentzkow (2012) document two striking regularities. First, nearly $60 \%$ of the difference in brand shares between the state of origin and current state of residence appears to be eliminated almost immediately after moving. ${ }^{21}$ Evidence is provided both within and between households. Second, the remaining $40 \%$ of the gap closes very slowly, requiring more than 20 years to close even half the gap. Even migrants that moved before the age of five exhibit a small persistent gap. The authors conclude that "since the stock of past experiences has remained constant across the move, while the supply-side environment has changed, we infer that approximately 40 percent of the geographic variation in market shares is attributable to persistent brand preferences, with the rest driven by contemporaneous supply-side variables." Returning to our model in equation (1), these findings imply that approximately $40 \%$ of consumers' expected conditional indirect utility derives from $F_{j}\left(H_{t}\right)$ and $60 \%$ from $\mu_{j}\left(X_{t}\right)$. These findings are consistent with the long-term habit formation for food studied in Atkin (2013).

Collapsing their analysis by age cohorts, they find that "migrants who moved during childhood have relative shares close to those of nonmigrants in their current states, while those who move later look closer to nonmigrants in their birth states." This evidence is consistent with a theory of brand capital stock, whereby older migrants who have accumulated more brand capital would

\footnotetext{
${ }^{21}$ Mela, Gupta, and Lehmann (1997) also find that consumer brand preferences are responsive to shorter-term changes in point-of-purchase marketing efforts like discounts.
} 
exhibit more inertia. ${ }^{22}$ The authors use the data to estimate a simple model of demand with habit formation through a brand capital stock (Pollak, 1970; Becker and Murphy, 1988). Consumer choices are influenced by current marketing conditions and a brand capital stock reflecting historic brand consumption experiences.

To interpret these results, Bronnenberg, Dubé, and Gentzkow (2012) use a simple model of habit formation in which myopic consumers' brand choices each period depend on both contemporaneous marketing and on their stock of past consumption experiences. The key identifying assumptions are that "migration status is orthogonal to stable determinants of brand preferences" and that "a brand's past market share in a given market is equal in expectation to the share today." 23 The key result is that the impact of past consumption experiences depreciate at a rate of $2.5 \%$ per year. Several policy simulations indicate that this persistence in preferences is large enough to rationalize some of the persistent order-of-entry effects discussed in section 2.3.

\subsection{Brand Choice Inertia, Switching Costs and Loyalty}

Switching costs represent another highly-studied source of persistence in consumer demand. Klemperer (2005) explains: "A product exhibits classic switching costs if a buyer will purchase it repeatedly and find it costly to switch from one seller to another." It is unlikely that consumers literally face a financial switching cost from switching between typical CPG brands, unlike for instance the software costs associated with changing one's operating system on a computer. However, consumer psychologists have studied psychological switching costs as a source of repeat-purchase behavior (see for instance Mittelstaedt, 1969 and the survey of psychological theories of repeatbuying by Muthukrishnan, 2015). In the CPG industry, analysis of household purchase histories routinely find that brand switching rates are, on average, quite low (Dekimpe, Steenkamp, Mellens, and Vanden Abeele, 1997) and that "in a typical grocery product category, where availability

\footnotetext{
${ }^{22}$ The evidence is, however, also consistent with the literature on the "aging consumer." Studies in (neuro)psychology on the relation between age and consumption report that cognition and memory decline with age, with working memory being more affected by age than long term memory (Carpenter and Yoon, 2011). Processing of (new) information also declines with age and leads to aging consumers tending to choose from a smaller number of considered options (John and Cole, 1986) and engaging in less product comparisons Lambert-Pandraud, Laurent, and Lapersonne (2005). These factors contribute to a decline in the flexibility of purchasing patterns of the aging consumer (see also Drolet, Schwarz, and Yoon, 2010).

${ }^{23}$ These assumptions are tested using within-household data before and after moving, and with historic market share data from the 1940s to 1960 s.
} 
is often in the hundreds or even thousands of options, households on average spend about half of their total category expenditure over one year on one single product" (Hansen and Singh, 2015). This finding is particularly striking in CPG categories where consumers often cannot identify their preferred CPG brands in blind taste tests (e.g. Allison and Uhl 1964; Thumin 1962). Similar patterns of high repeat-purchase behavior have been documented in other settings where goods are relatively undifferentiated other than the brand names: health plans (Handel, 2013a), auto insurance (Honka, 2014), broadband service (Liu, Chintagunta, and Zhu, 2010), ${ }^{24}$ and mobile phone services. $^{25}$

Interestingly, Klemperer (2005) associates the origins of the literature on switching costs to Selten (1965)'s model of demand inertia. One of the oldest and most widely-studied empirical topics in the marketing literature is the analysis of "brand loyalty" as a source of demand inertia. In the early 1950s, Advertising Age sponsored a research relationship between the Chicago Tribune and the University of Chicago to study brand loyalty patterns using a novel, household-level diary purchase panel (Brown, 1952, 1953). Loyalty was defined based on patterns of inertia (or repeat-buying) in the observed household brand choice sequences. The initial findings revealed a large number of households that exhibited long spells of repeat-buying of the same brand over time. Nevertheless, many households routinely switch between brands over time, in contrast with the assumption of an infinite switching cost often assumed in the theoretical microeconomics literature (e.g. Beggs and Klemperer, 1992) and in some of the psychology literature (e.g. Berkman, Lindquist, and Sirgy 1997, pp. 422-3). A brand choice theory with infinite switching costs is consistent with the view discussed in section 3.2 that brand preferences are fully-developed during childhood and reflect parental brand preferences.

With the advent of CPG shopping diary panels, a literature emerged studying patterns of inertia in brand choices and testing the order of the stochastic brand choice process. The basic idea consisted of testing for whether an observed household choice sequence looked like a "zero-order" Markov process versus some other higher-order Markov process. Rejection of the null hypothesis of "zero-order" choice behavior was interpreted as evidence of brand loyalty. Two classic references are Frank (1962) and Massy (1966) who applied a non-parametric binomial runs test to

\footnotetext{
${ }^{24}$ In December 2004, 95.7\% of the DSL market share was held by phone companies even though many 3rd-party DSL ISPs existed, some with award-winning service (see for instance https://ecfsapi.fcc.gov/file/6518051597.pdf).

${ }^{25}$ UBS (2013) reports that switching rates at U.S. mobile phone services are $1.1 \%$ at AT\&T and $0.91 \%$ at Verizon.
} 
individual choice histories to determine whether observed choices were zero order. Bass, Givon, Kalwani, Reibstein, and Wright (1984) provide an excellent survey of the subsequent literature that emerged and generalizations of the findings.

The findings in the literature are highly mixed regarding the fraction of households for which one can reject the null hypothesis of zero-order behavior. Many studies interpret a failure to reject the null as evidence against brand loyalty. However, the tests themselves are known to have relatively low statistical power, especially for choice histories with fewer than twenty observations (Massy, Montgomery, and Morrison 1970; Bass, Givon, Kalwani, Reibstein, and Wright 1984). Since most choice histories are relatively short (typically one or two years), it is unlikely that a pure "within-household" analysis will provide reliable evidence for loyalty and inertia. In addition, these tests are binary and cannot correctly account for the choice among many brands. Finally, the tests fail to control for point-of-purchase causal factors like prices and other marketing variables.

A more recent literature has adopted a more structural approach that models the multinomial nature of brand choices with controls for prices and other marketing variables (Jeuland, 1979; Guadagni and Little, 1983; Jones and Landwehr, 1988; Roy, Chintagunta, and Haldar, 1996; Keane, 1997; Seetharaman, Ainslie, and Chintagunta, 1999; Shum, 2004; Osborne, 2008; Dubé, Hitsch, and Rossi, 2010). The added structure of the choice model improves statistical power, and many authors have documented statistically and economically significant degrees of inertia. However, the recent literature has debated the interpretation of the inertia. One interpretation, termed "structural state dependence" (Heckman, 1981), involves a causal link between past and current brand choices, i.e. true "brand loyalty." Alternatively, inertia could arise due to serially correlated unobserved sources of between-consumer heterogeneity, a phenomenon termed "spurious state dependence" (Heckman, 1981) and recognized as a confound to the empirical finding of "brand loyalty" at least since Massy (1966).

Consider the following re-formulation of the model of the conditional indirect utility for a consumer $h$ choosing brand $j$ from among $J$ alternatives on trip $t$ :

$$
u_{j t}^{h}=\lambda_{j}^{h}+\alpha^{h} X_{j t}+\gamma^{h} \mathbb{I}_{\left\{s_{t}^{h}=j\right\}}+\varepsilon_{j t}^{h}, j=1, \ldots, J
$$

where $X_{j t}$ are the marketing conditions for brand $j$ (e.g. it's price), $s_{t}^{h} \in\{1, \ldots, J\}$ is consumer $h^{\prime} s$ 
"loyalty" state, defined as the previously purchased brand, and $\Theta^{h}=\left(\lambda_{1}^{h}, \ldots, \lambda_{J}^{h}, \alpha^{h}, \gamma^{h}\right)^{\prime}$ are structural parameters to be estimated. The term $\varepsilon_{j t}^{h}$ is a random utility disturbance for each shopping trip. For instance, if we assume $\varepsilon_{j t}^{h}$ are i.i.d. draws from a Type I Extreme Value distribution, we have the familiar conditional logit model of demand. Equation (2) is a very simple, but commonly used, specification that allows the observed choice process to be first-order Markov or zero order Markov. A test for zero-order choice behavior would consist of the null:

$$
H_{0:} E\left(\gamma^{h}\right)=0
$$

where $E\left(\gamma^{h}\right)>0$ implies inertia and $E\left(\gamma^{h}\right)<0$ implies variety-seeking. In practice, the researcher could specify a more general specification that both relaxes the linearity and also allows for a higher-order choice process that depends on a more general function of the choice history rather than focusing on "previous choice." 26

In practice, unless the researcher adequately controls for heterogeneity (observed and unobserved) between consumers, a rejection of the null in equation (3) could merely constitute spurious state dependence. Keane (1997) and Dubé, Hitsch, and Rossi (2010) apply rigorous controls for persistent, unobserved heterogeneity in $\Theta^{h}$ and serial dependence in $\varepsilon_{j t}^{h}{ }^{27}$ The authors find statistically and economically significant levels of structural state dependence; although the magnitudes decline substantially after controlling for heterogeneity. Dubé, Hitsch, and Rossi (2010) estimate median levels of $\gamma$ that are equivalent to $21 \%$ of the magnitude of average prices in the refrigerated orange juice category. These magnitudes more than double in analogous models without controls for unobserved heterogeneity. Nevertheless, the empirical magnitudes of switching costs are sufficiently small to rule out perfect lock-in (or infinite switching costs), which are often assumed in the theoretical literature.

The results suggest that many households form short-term brand-buying habits that would create persistence in their observed choices over time. Dubé, Hitsch, and Rossi (2010) test between

\footnotetext{
${ }^{26}$ Keane (1997) and Guadagni and Little (1983) use a non-Markov specification in which loyalty is modeled as an exponentially smoothed weighted average of a consumer's entire observed choice history.

${ }^{27}$ When the researcher does not observe consumers' initial choices, an "initial conditions" bias can also arise from the endogeneity in consumers' initial observed (to the researcher) states. Handel (2013a) avoids this problem in his analysis of health plan choices. He exploits an intervention by an employer that changed the set of available health plans and forced employees to make a new choice from this changed menu.
} 
several potential underlying mechanisms for this state dependence including: loyalty, price search, and learning. They conclude that "loyalty" is most consistent with their data and that $\gamma$ can be interpreted as a deep structural parameter.

The loyalty term $\gamma$ in equation (2) is analogous to the typical microeconomic formulations of switching costs (Klemperer, 1987; Beggs and Klemperer, 1992). Dubé, Hitsch, and Rossi (2009) explore the implications of their estimated switching costs for consumer brand prices and find that, contrary to the conventional wisdom (e.g. Farrell and Klemperer, 2007), the presence of such switching costs can toughen price competition and lead to lower equilibrium price levels.

The evidence for brand loyalty is nevertheless insufficient to understand the decades-long patterns of brand share persistence discussed in section 2.3. Consider again the model of conditional indirect utility in equation (2) above. The model includes brand-specific intercepts, $\lambda_{j}$, to control for persistent intrinsic preferences for the brand itself. Even after controlling for inertia, $\gamma$, Keane (1997) and Dubé, Hitsch, and Rossi (2010) find very large brand intercepts. Keane (1997) and Seetheraman (2004) find large brand-specific heterogeneity components even after allowing for more sophisticated non-Markovian choice processes in which loyalty depends on a consumer's entire observed choice history. Since most brand choice studies use approximately one or two years of observed choices, the brand intercepts, $\lambda_{j}$, are typically treated as "nuisance" parameters in this literature. But, they represent persistent sources of brand preferences that are not accounted for by "loyalty" (or brand-buying habits) over the typical time horizons studied. Moreover, these persistent brand tastes, $\lambda_{j}$, are much more predictive of brand choices than the inertia created through the loyalty term. In economic terms, the psychological switching costs create short-term inertia in brand choices, but are much smaller than the persistent source of brand tastes in the intercepts of most brand choice models of demand. Using the posterior mean hyper-parameter values from the 5-component mixture estimates of demand for margarine in Dubé, Hitsch, and Rossi (2010), the importance weights for loyalty, price and brand are $6.4 \%, 53.6 \%$ and $40 \%$ respectively. ${ }^{28}$ Part

\footnotetext{
${ }^{28}$ Following the convention in the literature on conjoint analysis, an importance weight approximately describes the percentage of utility deriving from a given component. The model in equation 2 has three components to utility: brand, marketing variables and loyalty with respective part-worths (or marginal utilities) $P W^{\text {brand }}($ brand $=j)=\lambda_{j}-\min \left(0,\left\{\lambda_{k}\right\}_{k=1}^{J}\right), P W^{\text {marketing }}\left(X_{j t}=x\right)=\alpha(x-\min (x))$ and $P W^{\text {loyalty }}\left(s_{j t}=j\right)=\gamma$. We can then assign an importance weight to each of these components, scaled to sum to one, as follows: $I W_{\text {brand }}=\frac{\max \left(P W^{\text {brand }}\right)}{\max \left(P W^{\text {brand }}\right)+\max \left(P W^{\text {price }}\right)+\max \left(P W^{\text {loyalty }}\right)}, I W_{\text {price }}=\frac{\max \left(P W^{\text {price }}\right)}{\max \left(P W^{\text {brand }}\right)+\max \left(P W^{\text {price }}\right)+\max \left(P W^{\text {loyalty }}\right)}$ and $I W_{\text {loyalty }}=$ $\frac{\max \left(P W^{\text {loyalty }}\right)}{\max \left(P W^{\text {brand }}\right)+\max \left(P W^{\text {price }}\right)+\max \left(P W^{\text {loyalty }}\right)}$.
} 
of $\lambda_{j}$ could reflect unobserved (to the researcher) product characteristics in $\mu_{j}\left(X_{t}\right)$; but $\lambda_{j}$ could also include some of the slowly-evolving component of tastes due to lifetime brand purchase and consumption experiences, $F_{j}\left(H_{t}\right)$. In the latter scenario, brand habits may still arise, but over a much longer time horizon than the ones typically studied in the brand loyalty literature.

\subsection{Advertising and Brand Goodwill}

The literature on persuasive advertising also has a tradition of modeling the persistent effects of past advertising as a goodwill stock (see Bagwell, 2007 for a survey). Such advertising investments have long been considered to constitute important barriers to entry (Bain, 1956; Sutton, 1991). To the extent that brand preference reflects past advertising, the finding of a stock of persistent brand capital, $F_{j}\left(H_{t}\right)$, could be picking up past exposure to advertising and branding. A long empirical literature has attempted to estimate the long-run effects of advertising on demand using aggregate data (see, e.g., Leone, 1995). A detailed discussion about the econometric challenges with identifying consistent advertising effects is beyond the scope of this survey.

Under sequential entry, when advertising investments in the goodwill stock are fixed and sunk, an early entrant faces investment incentives to deter future entry. In some cases, an early entrant may invest in a large goodwill stock to soften the effect of future competition (Schmalensee, 1983; Fudenberg and Tirole, 1984). A related literature has studied the entry-deterring effects of large fixed investments in a sustainable product quality advantage to deter later entrants or to soften future competition post entry (Lane, 1980; Moorthy, 1988; Sutton, 1991; Lehmann-Grube, 1997; Bronnenberg, 2008). More recently, Doraszelski and Markovich (2007) show how initial advantages to one firm can persist in the long-term using a more realistic model with an infinite horizon and firms investing in competing, depreciating advertising stocks. These predictions for earlymover effects in an advertising game with sunk investments in a goodwill stock are consistent with the empirical findings of an order-of-entry effect on brand market shares discussed in section 2.3 above. 


\subsection{Brands and Consumer Information}

Intro An important historical motivation for the emergence of brands and trademarks is that they "assured the buyer or trader of the quality of the merchandise" (Landa, 2006) in a time where information about the maker or seller of the merchandise was often impossible to obtain directly. This consumer uncertainty about product quality has often been cited as one of the main roles of brands and economists have long speculated about the consequences of consumer reliance on brands as a proxy for objective product quality. As discussed in Bronnenberg, Dubé, Gentzkow, and Shapiro (2015): "Braithwaite (1928) writes that advertisements "exaggerate the uses and merits" of national brands, citing aspirin and soap flakes as examples. Simons (1948) advocates government regulation of advertising to help mitigate "the uninformed consumer's rational disposition to 'play safe' by buying recognized, national brands" (1948, 247). Scherer (1970) discusses premium prices for national-brand drugs and bleach, and writes that "it is hard to avoid concluding that if the housewife- consumer were informed about the merits of alternative products by some medium more objective than advertising and other image-enhancing devices, her readiness to pay price premiums as large as those observed here would be attenuated" (1970, 329-332)." Nelson (1970) concluded that "limitations of consumer information about quality have profound effects upon the market structure of consumer goods."

Consumer knowledge and shopping expertise We begin by describing consumers' knowledge about products and the association with market structure. In some instances, a brand may indeed convey reliable information about a product. For instance, Marquardt and McGann (1975) find a positive correlation between advertising and Consumer Reports product ratings. However, striking levels of price dispersion have been documented in markets with relatively homogeneous goods differentiated mainly by brand names that command a high price premium: mutual funds (Hortacsu and Syverson, 2004), fund managers (Hastings, Hortacsu, and Syverson, 2013), online book vendors (Brynjolfsson and Smith, 2000), twin-automobiles (Sullivan, 1998), health insurance Handel (2013b), and pharmaceuticals Hurwitz and Caves (1988). Particularly striking is the prevalence of consumer spending on nationally branded goods when a cheaper and comparable store brand (or private label) is available. In an analysis of nearly 38,000 stores across over 100 chains, Bronnenberg, Dubé, Gentzkow, and Shapiro (2015) “find that consumers would spend \$44 
billion less per year on consumer packaged goods (CPG) if they switched from a national brand to a store brand alternative whenever possible." In the US, the private label sector is still surprisingly under-developed relative to other western countries, representing only $18 \%$ of 2014 CPG expenditures, versus a $16.5 \%$ weighted global average and rates exceeding $40 \%$ in the UK, Switzerland and Germany (The Nielsen Company, 2014). In several CPG categories, Erdem, Zhao, and Valenzuela (2004) find evidence for more consumer uncertainty about the quality of private labels in the US than in the European countries they analyze.

The literature on consumer behavior routinely finds that consumers shop with limited information. In-store interviews find that most consumers rarely engage in price comparisons and are unable to recall product prices even for goods that they have just put in their baskets (Dickson and Sawyer, 1990). Observing consumers in the detergent aisle of a supermarket, Hoyer (1984) documents very limited price search: only $8 \%$ of consumers inspected a single shelf tag and only $3 \%$ inspected more than a single tag. Consumers also appear to lack brand information. In branding experiments, consumers routinely fail to identify their preferred brands in blind taste tests (Husband and Godfrey, 1934; Thumin, 1962; Allison and Uhl, 1964, p. 336).

Bronnenberg, Dubé, Gentzkow, and Shapiro (2015) provide empirical evidence for systematic differences in the shopping behavior of experts and non-experts. They match a CPG shopping panel for almost 90,000 households with survey-based information about each panelist's professional occupation and product knowledge for selective product categories. After controlling for income and socio-economic status, consumers with a health-related occupation are considerably more likely to buy unbranded (i.e. store brand) health-related CPG products than consumers in other non-health occupations. For instance, pharmacists purchase more than $91 \%$ unbranded over-the-counter pain medications, whereas the overall average market share for these products is only $65 \%$. There is also a high association between the purchase of unbranded pain medications and the consumer's knowledge of the active ingredients in typical over-the-counter pain medications. Similarly, consumers with an occupation related to food preparation or food production are considerably more likely to buy unbranded CPG pantry staples, like sugar, salt and flour. This link between occupation and preference for private labels is domain specific: health professionals are not more likely to buy private label food staples than other households with comparable socio-economic status who do not have a food-related occupation. 
Generic alternatives to several of the CPG brands studied in Bronnenberg, Dubé, Gentzkow, and Shapiro (2015) have been available for decades, suggesting that consumers remain persistently uninformed. ${ }^{29}$ Several market frictions can potentially limit consumers' endogenous gathering of information, or "search." Nelson (1970) makes a distinction between "search characteristics", which can be determined prior to purchase, and "experience characteristics," which are determined after purchase through trial and consumption. We now discuss various mechanisms on the supply and demand sides that can influence the amount of information consumers obtain for both search and experience characteristics of products.

The supply of Product Quality Information Theorists have studied firm's incentives to supply product information through branding and brand advertising. Advertising can directly convey information regarding search characteristics, including prices, product features, availability, and other search attributes. Advertising can also indirectly convey information regarding experience characteristics like product quality. The "money burning" theory of advertising postulates that, in equilibrium, advertising can indirectly convey information about product quality if firms with high-quality products optimally invest more in advertising than firms with low-quality products (Nelson 1974; Kihlstrom and Riordan 1984; Milgrom and Roberts 1986 and see Bagwell 2007 for a comprehensive survey of the literature on advertising and product quality). Nelson (1974) observes a higher advertising-to-sales ratio for experience goods than search goods. In an empirical analysis of consumer exposure to advertising before and after the first trial of a newly-launched yogurt product, Ackerberg (2001) only finds a significant advertising effect for inexperienced users who had not yet purchased the new product. Similarly, Sovinsky Goeree (2008) finds that informative advertising affects the likelihood that a computer brand enters consumers' consideration sets; although she models the consideration set in a reduced form.

These theories of informative advertising assume a rational consumer. A more recent behavioral economics literature has studied the incentives for firms to withhold information when selling to boundedly rational consumers. For instance, Gabaix and Laibson (2006) consider a market where firms sell to a mix of expert and non-expert (myopic) consumers. In this case, sellers optimally withhold information ("shrouding"), for instance regarding add-on prices, to exploit the

\footnotetext{
${ }^{29}$ The brand price premium has been attributed to consumer misinformation for Bayer aspirin and soapflakes (Braithwaite, 1928) and bleaches and detergents (Scherer, 1970).
} 
myopic non-expert consumers. Interestingly, firms would not engage in educational advertising or marketing to inform consumers about competitors' add-on practices even if such advertising was costless. In fact, McDevit (2014) studies cases where firms that advertise provide relatively low quality. For instance, firms with brand names starting with "A" or a number tend to charge higher prices and receive more service complaints. Similarly, firms that purchase ads in Yellow pages or on Google are found to provide lower-quality service. McDevit (2014) rationalizes these patterns with a model in which, in equilibrium, uninformed consumers with relatively low willingness to search will settle for easily-found firms (i.e. at start of an alphabetical list or with prominent position ads).

Consumer Learning about the Quality of Brands On the demand side, consumers may also gather information on experience characteristics through their endogenous purchase and consumption decisions. The rate at which consumers learn through trial and consumption can be critical for whether or not they will experiment with new products and learn the objective qualities of substitute brands. Even in a model with consumer learning about product quality where both brands may be valued equally ex post, if the purchase frequency is "too low" a consumer will still prefer to continue buying the known pioneering brand and will not become informed about the quality of newly launched substitute products (Schmalensee, 1982a). Consumer learning rates can therefore affect the industrial market structure, creating a sustainable advantage to pioneers.

An empirical literature has studied consumers' learning rates through purchase and experimentation. Using diary shopping panels, Demsetz (1962) documents suggestive evidence that consumers do eventually learn about products and that the advantages to branded goods might erode relatively quickly over the course of a few years. However, more recent evidence on product learning rates has been mixed. Consumer psychologists have studied how "blocking" can prevent consumers from learning about objective product characteristics. If a consumer initially learns to use the brand name to predict an outcome (e.g. taste quality or headache relief), "subsequent learning of the importance of another characteristic (e.g. a grape varietal or an active ingredient) may be blocked" (Van Osselaer, 2008). In contrast, econometric evidence from the analysis of brand choice panel data using structural models of demand with Normal Bayesian learning about product quality has generated relatively fast estimated rates of learning that may only require a few 
purchase/consumption occasions (e.g., Erdem and Keane, 1996; Ackerberg, 2003; Crawford and Shum, 2005).

A concern with the structural evidence for consumer learning is the potential "initial conditions" bias associated with consumers' initial beliefs at the start of the data sample. Most studies do not observe consumer choices from the initial trial and therefore need to make untestable assumptions about initial product quality beliefs. Typically, researchers assume homogeneous prior beliefs across consumers at the start of the sample period, which could falsely attribute learning to unobserved heterogeneity across consumers in their initial product knowledge at the start of the sample period. ${ }^{30}$ To resolve this bias, Shin, Misra, and Horsky (2012) match consumer shopping panel data for toothpaste with a household-level survey on product quality beliefs conducted immediately before the start of the panel period. Once the survey data are used to calibrate initial beliefs, the authors find considerably slower rates of learning. ${ }^{31}$ These findings are suggestive that product information could persist as a barrier-to-entry, granting an advantage to pioneering brands as in Schmalensee (1982a). In the context of durable consumer goods, Erdem, Keane, Öncü, and Strebel (2005) tackle a related identification problem that arises when product quality learning rates and declining prices (e.g. price skimming) co-move over time. They supplement their purchase panel data with survey data on price and quality expectations to resolve the separate identification of learning about product quality and expectations of declining future prices. These survey data also allow them to relax the standard "rational expectations" assumption typically used in the empirical literature on dynamic discrete choice.

Consumer Search for Brand Information A separate empirical literature has studied how consumers gather information about "search characteristics" prior to purchase, in the spirit of the theoretical literature on price search and match-value search (Stigler, 1961; Weitzman, 1979). Previous work has found that consumers engage in relatively limited search prior to purchase (Beatty and Smith, 1987; Moorthy, Ratchford, and Talukdar, 1997). Several authors have documented an inverted U-shaped relationship between a consumer's experience in a product category and

\footnotetext{
${ }^{30}$ One exception is Ackerberg (2003) who resolves this problem by focusing on learning about one, recentlylaunched brand. He can then study consumer choices before versus after the initial trial.

${ }^{31}$ Other work has also found that self-reported survey measures of uncertainty about brand quality and reliability are correlated with actual brand purchase choices and with brand purchase intentions (e.g., Erdem and Swait, 1998; Erdem, Swait, and Louviere, 2002).
} 
the extent to which she engages in information search prior to purchase (Moorthy, Ratchford, and Talukdar, 1997; Punj and Staelin, 1983), reflecting the trade-offs between information and prior knowledge. A recent empirical literature has used structural approaches to study the interdependence of consumer choices and consumer search behavior when aspects of product quality are uncertain prior to purchase (see, e.g., Kim, Albuquerque, and Bronnenberg, 2010; Koulayev, 2014; Jeziorski and Segal, 2015; Moraga-Gonzalez, Sandor, and Wildenbeest, 2015). ${ }^{32}$ These papers find relatively high estimated search costs and, consequently, very limited consumer "consideration sets." In a case study of digital camcorders on Amazon.com, Kim, Albuquerque, and Bronnenberg (2010) find that consumers typically consider a very small fraction of the total set of available products and that established brands, like Sony, have a much higher presence in these consideration sets. Similarly, Honka (2014) finds that consumers obtain price quotes from, on average, only 2.96 auto insurance providers in a given year (including their current provider) even though consumers in her data collectively choose among 17 providers and there are at least 141 providers in total in the $\mathrm{US}^{33}$. Even among those that switch, the average consumer obtains only 3.51 price quotes (including their current provider). Geico, the largest-share provider and a heavy advertiser, is in over half of the consumers' consideration sets. As in Schmalensee (1982a), these information advantages to established brands could create barriers to entry for newer products.

From an econometric perspective, failure to account for the search process and the consumer's "considered" set of brands can also bias the estimates of consumers' brand preferences. High repeat-purchase rates for brands could be falsely attributed to brand preferences when search costs are not accounted for (see, e.g., Honka, 2014; Hortacsu and Syverson, 2004; Sovinsky Goeree, 2008). This bias in estimates of brand preference can emerge even in contexts where the researcher assumes consumers are fully informed about product qualities and engage only in price search. Identifying search costs separately from preferences typically requires data on the search process or the consideration set (see, e.g., Honka, 2014; de los Santos, Hortacsu, and Wildenbeest, 2012; Koulayev, 2014). Alternatively, Hortacsu and Syverson (2004) supplement demand-side moments with supply-side moments based on equilibrium prices under a specific search conduct, and Moraga-Gonzalez, Sandor, and Wildenbeest (2015) use exogenous shifters of search costs.

\footnotetext{
${ }^{32}$ Sovinsky Goeree (2008) does not formally study the underlying search process, but allows for informative advertising to influence consumers' consideration sets for computers.

${ }^{33}$ https://en.wikipedia.org/wiki/List_of_United_States_insurance_companies accessed on 9-14-2016.
} 
Theorists have studied firms' incentives to influence the magnitude of consumer search costs through information disclosure. Zettelmeyer (1995) finds that firms may endogenously choose not to facilitate consumer search through information disclosure, even if it is costless to do so. Theorists have also studied mechanisms through which firms can further reduce the discovery of information on "search characteristics" by engaging in obfuscation strategies that increase consumer search costs and, thus, the prices paid by consumers in equilibrium (e.g., Ellison and Wolitzky, 2012; Gabaix and Laibson, 2006; Piccione and Spiegler, 2012; Wolinsky, 1987). Such obfuscation strategies have been documented as a supply-side response to new information technologies, such as price comparison websites, that facilitate consumer search (Ellison and Fisher Ellison, 2009).

Brand Information Interventions We now discuss potential information policy interventions that could be used to inform consumers about objective product quality. Several studies have successfully documented an effect from the provision of calorie information on caloric consumption (Bollinger, Leslie, and Sorensen, 2011) and from hygiene-related information on restaurant choices (Jin and Leslie, 2003). However, attempts to provide information to overcome the brand versus (unbranded) private label preference gap have been mostly unsuccessful. In a study of product information disclosure for relatively homogeneous goods, Cox, Coney, and Ruppe (1983) found that few subjects switched to a cheaper private label alternative even after being informed of the objective similarity to the more expensive branded alternatives. In a cross-store field experiment, Carrera and Villas-Boas (2015) find that posting objective information about the comparability of branded and private label headache medicines does not lead to a discernible increase in demand for the private labels, which sell at lower prices. ${ }^{34}$ A psychological "signal learning" explanation may partly explain the difficulties in overcoming brand preference. As explained in Van Osselaer (2008): "if consumers first learn to predict an outcome (e.g., taste quality or headache relief) based on a brand name (e.g., of a wine or headache medicine), subsequent learning of the importance of another characteristic (e.g., a grape varietal or an active ingredient) may be blocked."

Bronnenberg, Dubé, and Sanders (2016) conduct in-store blind taste tests in which consumers compared a private label food product to the leading national brand in its category. The advantage of the taste test is that the consumer experiences the subjective consumption experience without

\footnotetext{
${ }^{34}$ The authors do find a positive effect of information about the number of "peers" that buy the unbranded alternative.
} 
the confounding signal from the brand itself. Surprisingly, over $75 \%$ of the participants chose the private label in the blind taste test even though only $40 \%$ predicted they would do so. By matching the taste test data with actual loyalty card shopping panel data, the authors use quasi-experimental methods to test for a persistent effect from the information conveyed in the taste test. While they observe a large short-term effect - the private label demand increases by almost 20 percentage points during the week after the tests - the blind taste test effect weakens considerably over time. By 5 months after the test, the treatment effect is only about 1.5 percentage points which may be suggestive of forgetting or may reflect the neutralizing effect of national brand marketing efforts.

Summary Summarizing, consumers often make brand purchase decisions with limited information about the availability of products, their prices, and their objective qualities. The extant literature has demonstrated that such limited information can favor established brands. In some cases, consumers may be willing to pay large brand price premia even when comparable products are available at lower prices. On the supply side, firms' incentives to supply objective product information may be limited. Moreover, evidence from various field studies suggests that the ability to "treat" consumers with objective product information requires more than mere disclosure.

\section{Brand Capital and Variety}

A long theoretical literature has analyzed the factors governing the equilibrium supply of product variety within a product category (e.g., Chamberlin, 1933; Dixit and Stiglitz, 1977; Spence, 1976). In this section, we discuss the related literature on the strategic implications of brand capital and firms' incentives to launch new brands into markets.

\subsection{Brand Proliferation}

The Federal Trade Commission's complaint ${ }^{35}$ against the four largest ready-to-eat cereal manufacturers in 1972 stimulated academic interest in the concept of brand proliferation and its potentially anti-competitive effects. Between 1950 and 1972, the six largest manufacturers launched over 80 brands (Schmalensee, 1978). Between 1974 and 1980, the top four firms in the ready-to-eat

\footnotetext{
${ }^{35}$ FTC v. Kellogg et al., Docket No. 8883.
} 
breakfast cereal industry launched 33 new brands (Raubitschek, 1988). Surprisingly, $42 \%$ of these brands failed and 21\% failed to achieve a non-trivial market share. Between 1985 and 1992, 78 new cereal brands were launched by the largest manufacturers. However, only one of these brands succeeded in becoming an established brand (Hitsch, 2006).

Theorists have debated the underlying mechanisms leading to the proliferation of brands. Schmalensee (1978) argued that cereal brand proliferation was the outcome of a multi-period game in which incumbents crowded the product space to deter future entry. If the launch of new brands requires large, exogenous fixed and sunk development (e.g. advertising) costs, incumbents can preempt future entry by "crowding" the product space. Such new brand launch costs can vary from $\$ 50$ million to $\$ 100$ million (Aaker, 1990). This theory has subsequently been criticized on the theoretical grounds that such preemptive product proliferation is only credible in the presence of high exit costs (Judd, 1985), a questionable assumption for most CPG categories.

Sutton (1991) also questioned the validity of the assumption of exogenous sunk costs for the launch of new consumer brands. When firms can strategically choose the magnitude of the sunk investment to build vertical differentiation (e.g., a higher-quality brand image), one would not expect a competitive escalation in the launch of new brands. Rather, one would expect an escalation in advertising spending as firms compete to build better (not more) brands. Using a broad, crossindustry approach, Sutton (1991) and Bronnenberg, Dhar, and Dubé (2011) provide empirical evidence of a competitive escalation in the level of CPG advertising expenditures and not in the number of advertised CPG brands in larger markets. Consistent with the theory of exogenous sunk costs Bronnenberg, Dhar, and Dubé (2011) do however observe an escalation in the number of non-advertised "local" (or "fringe") CPG brands..

Demand uncertainty provides an alternative mechanism for brand proliferation along with an explanation for the low success rate of new launches. Raubitschek (1988) proposes a simple twostage model in which firms first choose how many products to launch, under demand uncertainty, and then compete in the product market. The equilibrium number of products launched by a firm increases with the probability of product success. More recently, Hitsch (2006) studies the high failure rate of new cereal brands. He considers a model in which a firm faces demand uncertainty and sequentially learns the product's profitability by observing sales each period. In particular, he formalizes the product launch and exit problem as a real option problem. Numerical simula- 
tions calibrated with cereal demand estimates indicate that the firm's value of reducing demand uncertainty is sufficiently high that, as uncertainty rises, firms should be more likely to launch new products even when the expected profits are negative.

\subsection{Umbrella Branding}

The extant literature on branding has studied yet another important form of brand capital: brand quality reputation. Many of the new brand launches in consumer industries are simply extensions of an existing brand, such as Coca-Cola's launch of Diet Coke in the diet cola category in $1982 .{ }^{36}$ A firm with an established brand can leverage the strong brand reputation through brand extensions in new product categories. Aaker (1990) enumerates several risks associated with the extension of an established brand to a new product, a practice also known as "umbrella branding." Any failures or negative associations with the extension could harm the original brand's "reputation." 37 Nevertheless, according to Aaker (1990), forty percent of the new brands launched in US supermarkets between 1977 and 1984 were brand extensions. Amongst 7,000 new products launched in supermarkets during the 1970s, only 93 grossed over \$15 million and two thirds of these were brand extensions.

A theoretical literature on brand reputation has emerged that studies the practice of brand extension as a signaling equilibrium. The basic premise involves consumer uncertainy about the quality of new products. Consumers rely on brand reputation as a signal of product quality. By extending its established brand name to new products, a firm can signal high quality. ${ }^{38}$ However, brand extensions to low quality products will damage the future reputation of the brand and hence the future profitability of the firm. In Wernerfelt (1988), firms face a cost to extend the brand and consumers are uncertain about the quality of both the established branded product and the new product. When the firm extends the brand to a new, low-quality product, consumers form less

\footnotetext{
${ }^{36}$ https://en.wikipedia.org/wiki/Diet_Coke

${ }^{37}$ Consumer psychologists have found mixed evidence on such spillovers. For instance, a poor experience with a new brand extension may be attributed to the extension component and not to the original brand, limiting feedback in the original category (Van Osselaer, 2008).

${ }^{38}$ Here too, the evidence from consumer psychology has been mixed. For instance, if a well-known product that carries only a family brand name (e.g., Godiva chocolate) adds a subbranded product (e.g., L'Amour by Godiva chocolate truffles) with the same outcomes (e.g., identical levels of quality) to its product portfolio, learning about or forming associations with the sub-brand name could be "blocked.'If the sub-brand is inferior, it may protect the family brand by absorbing any negative brand equity (Van Osselaer, 2008).
} 
favorable beliefs about the quality of the established product, reducing their future demand for the established product. In Choi (1998), a multi-product monopolist considers branding a future stream of new product opportunities with the same name as its high-quality established product. A low-quality brand extension damages the reputational capital of the brand, thereby reducing the positive signal for all future brand extensions. ${ }^{39}$ In Cabral (2000), a firm's product qualities are correlated and consumer learning about new products with the same brand name will feedback on their willingness-to-pay for older products. In all of these models, there exists a separating equilibrium in which only firms with high-quality products use brand extensions. ${ }^{40}$

The empirical evidence in the field for such spillovers in consumer quality beliefs is limited. Erdem and Winer (1999) fit a structural model of demand to consumer purchase panel data for toothbrushes and toothpaste. The parameter estimates imply correlation in how consumers perceive a brand across categories. Using the same data, Erdem (1998) fits a structural model of demand with Normal Bayesian learning about product qualities in the two categories. Her parameter estimates imply that consumers' prior beliefs about brand qualities are correlated between the two categories, which would allow for learning spillovers. Erdem and Sun (2002) extend the model to allow for learning effects from marketing decisions like advertising and promotion. The parameter estimates imply that advertising and promotion not only reduce uncertainty about product quality, these effects can spillover across the two categories.

The reputational cost from extending a brand to a low-quality new product also potentially creates an implicit exit cost if the new product fails, damaging the reputation of the brand and any future profit opportunities from the brand including the sales of established products. Thomas (1996) conjectures that this exit cost creates a credible entry-deterring motive for brand extensions. The empirical evidence is mixed. In case studies of the US beer, coffee and soft drink categories, Thomas (1995) finds that firms with established brand leaders are typically first to enter new submarkets. However, in a comprehensive analysis of 95 brands across 11 CPG categories, Sullivan (1992) finds that new brands typically enter earlier into new product markets than brand extensions. However, brand extensions that enter later are more likely to succeed in the long run and typically

\footnotetext{
${ }^{39}$ Specifically, the firm uses price as a signal. Reputational capital reduces the extent to which price distortions are required to signal high quality.

${ }^{40}$ Moorthy (2012) critiques the off-equilibrium beliefs typically used in the models. A refinement allowing for more realistic off-equilibrium beliefs diminishes the signaling capability of a brand extension.
} 
exhibit above-average market shares after controlling for order-of-entry and advertising.

The literature on umbrella branding reveals that firms with established brands and brand capital may be able to leverage the corresponding reputational benefits into new product markets. Therefore, brand capital may create barriers to entry for new firms not only within an existing product category, but also in related new product categories for which consumers may rely on the reputation of a previously-established brand.

\section{Conclusion}

The empirical regularities in the market structures of non-durable consumer goods industries reveal a persistent and central role for established brands. Most non-durable consumer goods industries are highly concentrated, with a small number of brands driving most of the market share. The identity of the dominant brands varies from country to country and, within the US, even from city to city. Surprisingly, this dominance persists for decades and, in some cases, ties back to the late nineteenth and early twentieth centuries when the categories themselves were still in their formative stages. The geographic variation in brand shares across US cities today is explained, at least to a large extent, by the historic order of entry amongst surviving brands.

In this review, we have surveyed an extensive literature in economics and marketing that studies various mechanisms through which established brands can figure prominently in the consideration sets of consumers, generating advantages both in awareness and willingness-to-pay. Brand experiences early in life have persistent effects on a consumer's brand choice behavior throughout her lifetime. Some of this persistence may reflect market frictions that prevent a consumer from becoming informed about competing brands and new products. Surprisingly, even in established categories with mature brands, consumers appear to shop with very limited information about the broad set of prices and product qualities for the available products. Empirical estimates of the costs of acquiring product information prior to purchase are found to be commensurately high. Consequently, consumers often consider only a small subset of the available products. Learning rates from trial and experimentation after purchase are also found to be slow, further reducing the ability for consumers to become "informed."

On the supply side, firms may lack incentives to facilitate the consumer search and learning 
processes through information disclosure, even when it is costless. In some settings, firms may endogenously obfuscate information to soften price competition. Even if such information disclosure was in the interest of firms, empirical evidence indicates the difficulties in conveying brand quality information to consumers in practice through informational interventions.

The body of literature and the collection of empirical evidence supports the long-standing notion that established brands constitute important barriers to entry (e.g., Bain, 1956; Demsetz, 1982; Schmalensee, 1982b). Consumer's brand capital stocks (consumption experiences and branding goodwill) combined with slow rates of learning and the costly acquisition of product information also suggest an early-mover advantage that can lead to persistent brand dominance in a product category. The brand capital stocks of established brands can also be leveraged to create strategic advantages in newly emerging markets through brand extensions and umbrella branding.

Most of the literature surveyed herein uses a microeconomic focus on the role of brands in specific markets and on consumer behavior within those markets. Product differentiation and imperfect competition have been considered in macroeconomic growth models, for instance to understand new-Keynesian patterns of nominal price rigitidy (e.g., Matsuyama, 1995) and R\&D and technological innovation through the emergence of new products (e.g., Grossman and Helpman, 1991, ch. 3). Product differentiation and imperfect competition have also been incorporated into models of trade to study the impact of international trade on intra-industry firm composition and aggregate industry productivity (e.g., Melitz, 2003). Given the empirical findings discussed herein, it could be interesting to consider the role of persistent brand preference and brand loyalty along with the corresponding brand capital stock in macroeconomic settings of trade and growth. An interesting first step in this direction is Ravn, Schmitt-Grohé, and Uribe (2006), who show that consumer habit formation and brand loyalty can help explain counter-cylical patterns in mark-ups. 


\section{References}

AAKER, D. A. (1990): "Brand Extensions: The Good, the Bad, and the Ugly," Sloan Management Review, 31, 47-56.

ACKerberG, D. A. (2001): "Empirically Distinguishing Informative and Prestige Effects of Advertising," RAND Journal of Economics, 32(2), 316-333.

(2003): “Advertising, Learning, and Consumer Choice in Experience Good Markets: An Empirical Examination,” International Economic Review, 44(3), 1007-1040.

AdAms, W. J. (2006): "Markets: Beer in Germany and the United States," The Journal of Economic Perspectives, 20(1), 189-205.

Albig, W. (1939): Public Opinion. McGraw Hill Book Company.

Allison, R. I., AND K. P. Uhl (1964): "Influence of Beer Brand Identification on Taste Perception," Journal of Marketing Research, 1(3), 36-39.

Anderson, S. T., R. Kellogg, A. LAnger, and J. M. SAlleE (2015): “The Intergenerational Transmission of Automobile Brand Preferences," Journal of Industrial Economics, 63(4), 763-793.

Ataman, M. B., C. F. Mela, And H. J. V. Heerde (2008): "Building Brands," Marketing Science, 27(6), 1036-1054.

AtKin, D. (2013): “Trade, Tastes, and Nutrition in India," American Economic Review, 103(5), $1629-1663$.

BAGWELL, K. (2007): Handbook of Industrial Organizationvol. 3, chap. The Economic Analysis of Advertising, pp. 1703-1844. North Holland.

BAIn, J. S. (1956): Barriers to New Competition. Cambridge: Harvard University Press.

BARTEls, R. (1976): The History of Marketing Thought. Grid Publishers, Columbus, OH.

Bass, F. M., M. M. Givon, M. U. Kalwani, D. Reibstein, and G. P. Wright (1984): “An Investigation into the Order of the Brand Choice Process," Marketing Science, 3(4), 267-287.

Beatty, S. E., And S. M. Smith (1987): "External Search Effort: An Investigation Across Several Product Categories,' Journal of Consumer Research, 14(1), 83-95.

Becker, G. S., And K. M. Murphy (1988): “A Theory of Rational Addiction,” Journal of Political Economy. (1993): “A Simple Theory of Advertising as a Good or Bad," Quarterly Journal of Economics, 108(4), 941-964.

Beggs, A., And P. Klemperer (1992): "Multi-Period Competition with Switching Costs," Econometrica, 60, 651-666. 
Berkman, H. W., J. D. Lindquist, And M. J. SiRgy (1997): Consumer Behavior: Concepts and Marketing Strategy. NTC Business Books.

Bollinger, B., P. Leslie, And A. Sorensen (2011): "Calorie Posting in Chain Restaurants," The American Economic Journal: Economic Policy, 3(1), 91-128.

Borkovsky, R. N., A. Goldfarb, A. M. Haviv, and S. Moorthy (2016): "Measuring and understanding brand value in a dynamic model of brand management," forthcoming, Marketing Science.

Braithwaite, D. (1928): “The Economic Effects of Advertisement," The Economic Journal, 38(149), 16-37.

BronnenberG, B. J. (2008): "Brand Competition in CPG Industries: Sustaining Large Local Advantages with Little Product Differentiation," Quantitative Marketing and Economics, 6(1), 79-107.

Bronnenberg, B. J., S. K. Dhar, And J.-P. Dubé (2007): “Consumer Packaged Goods in the United States: National Brands, Local Branding," Journal of Marketing Research, 44, 4-13.

(2009): "Brand History, Geography, and the Persistence of Brand Shares," Journal of Political Economy, 117, 87-115.

(2011): "Endogenous sunk costs and the geographic differences in the market structures of CPG categories," Quantitative Marketing and Economics, 9(1), 1-23.

Bronnenberg, B. J., J.-P. Dubé, And M. Gentzkow (2012): "The Evolution of Brand Preferences: Evidence from Consumer Migration," American Economic Review, 102(6), 24722508.

Bronnenberg, B. J., J.-P. Dubé, M. Gentzkow, and J. M. Shapiro (2015): “Do Pharmacists Buy Bayer? Sophisticated Shoppers and the Brand Premium," Quarterly Journal of Economics, 130.

Bronnenberg, B. J., J.-P. Dubé, And R. E. S Anders (2016): "Is There Proof is in the Eating? The Effect of In-Store Blind Taste Tests on Demand for Private Label Brands," Working Paper.

Bronnenberg, B. J., And P. B. Ellickson (2015): "Adolescence and the Path to Maturity in Global Retail,” Journal of Economic Perspectives, 29(4), 113-134.

BronnenberG, B. J., And V. MAHAJAn (2001): "Unobserved Retailer Behavior in Multimarket Data: Joint Spatial Dependence in Market Shares and Promotion Variables,", Marketing Science, 20(3), 284-299.

Brown, C. L., AND J. M. LATTIN (1994): "Investigating the Relationship between Time in Market and Pioneering Advantage," Management Science, 40(10), 1361-1369.

Brown, G. H. (1952): “Brand Loyalty Fact or Fiction,” Advertising Age, 9, 53-55. (1953): “Brand loyalty-fact or fiction," The Trademark Reporter, 43, 251-258. 
Brynjolfsson, E., And M. D. Smith (2000): "Frictionless Commerce? A Comparison of Internet and Conventional Retailers," Management Science, 46(4), 563-585.

CABRAL, L. M. B. (2000): "Stretching Firm and Brand Reputation," The RAND Journal of Economics, 31(4), 658-673.

Carlson, L., S. Grossbart, And A. Walsh (1990): "Mothers' Communication Orientation and Consumer-Socialization Tendencies," Journal of Advertising Research, 19(3), 27-38.

CArpenter, S. M., And C. Yoon (2011): “Aging and consumer decision making," Annals of the New York Academy of Sciences, 1235(1), E1-E12.

CARRERA, M., AND S. B. Villas-BoAs (2015): "Generic aversion and observational learning in the over-the-counter drug market," Working Paper.

Caves, R. E., And M. E. Porter (1980): “The Dynamics of Changing Seller Concentration,” The Journal of Industrial Economics, 29(1), 1-15.

Chamberlin, E. H. (1933): The Theory of Monopolistic Competition. Harvard University Press.

Chandon, P. J., J. W. Hutchinson, E. T. Bradlow, and S. H. Young (2009): "Does InStore Marketing Work? Effects of the Number and Position of Shelf Facings onBrand Attention and Evaluation at the Point of Purchase," Journal of Marketing, 73(6), 1-17.

Childers, T. L., And A. R. RAO (1992): “The Influence of Familial and Peer-based Reference Groups on Consumer Decisions," Journal of Consumer Research, 19, 198-211.

Choi, J. P. (1998): "Brand Extension as Informational Leverage," The Review of Economic Studies, 65(4), 655-669.

Committee on Definitions (1935): "Definitions of Marketing Terms . . . Consolidated Report of the Committee on Definitions," National Marketing Review, 1(2), 148-166.

Coutant, F. R. (1934): "Research as an Aid to Pricing and Production," American Marketing Journal, 1(3), 119-124.

Cox, S. R., K. A. CONEY, And P. F. Ruppe (1983): "The impact of comparative product ingredient information," Journal of Public Policy \& Marketing, 2, 57-69.

Crawford, G. S., AND M. Shum (2005): "Uncertainty and Learning in Pharmaceutical Demand," Econometrica, 73(4), 1137-1173.

De los Santos, B., A. Hortacsu, And M. R. Wildenbeest (2012): "Testing Models of Consumer Search Using Data on Web Browsing and Purchasing Behavior,' American Economic Review, 102(6), 2955-2980.

DeKimpe, M. G., And D. M. Hanssens (1995): "Empirical Generalizations about Market Evolution and Stationarity," Marketing Science, 14, 109-121. 
Dekimpe, M. G., J.-B. E. Steenkamp, M. Mellens, and P. Vanden Abeele (1997): “Decline and variability in brand loyalty," International Journal of Research in Marketing, 14, 405420.

Demsetz, H. (1962): "The Effect of Consumer Experience on Brand Loyalty and the Structure of Market Demand," Econometrica, 30(1), 22-33. (1982): “Barriers to Entry,” American Economic Review, 72(1), 47-57.

Dickson, P. R., AND A. G. SAWYER (1990): “The Price Knowledge and Search of Supermarket Shoppers," Journal of Marketing, 54(3), 42-53.

Dixit, A. K., And J. E. Stiglitz (1977): "Monopolistic Competition and Optimum Product Diversity," American Economic Review, 67(3), 297-308.

Doraszelski, U., And S. Markovich (2007): “Advertising Dynamics and Competitive Advantage," Rand Journal of Economics, 38, 557-592.

Drèze, X., S. J. Hoch, And M. E. PurK (1994): "Shelf Management and Space Elasticity," Journal of Retailing, 70(4), 301-326.

Drolet, A., N. Schwarz, And C. Yoon (2010): The Aging Consumer: Perspectives from Psychology and Economics. New York: Routlege.

Dubé, J.-P., G. J. Hitsch, And P. E. Rossi (2009): “Do Switching Costs Make Markets Less Competitive?," Journal of Marketing Research, 46, 435-445.

(2010): "State dependence and alternative explanations for consumer inertia," $R A N D$ Journal of Economics, 41(3), 417-445.

Ellison, G., And S. Fisher Ellison (2009): "Search, Obfuscation, and Price Elasticities on the Internet," Econometrica, 77(2), 427-452.

Ellison, G., ANd D. Fudenberg (1995): "Word-of-Mouth Communication and Social Learning," Quarterly Journal of Economics, 110(1), 93-125.

Ellison, G., AND A. WOLITZKY (2012): “A search cost model of obfuscation,” Rand Journal of Economics.

ERdeM, T. (1998): “An Empirical Analysis of Umbrella Branding," Journal of Marketing Research, 35(3), 339-351.

Erdem, T., And M. P. KeAne (1996): "Decision-Making Under Uncertainty: Capturing Dynamic Brand Choice Processes in Turbulent Consumer Goods Markets," Marketing Science, 15(1), 1-20.

Erdem, T., M. P. Keane, T. S. ÖnCü, And J. Strebel (2005): "Learning About Computers: An Analysis of Information Search and Technology Choice," Quantitative Marketing and Economics, 3, 207-246. 
ERdEM, T., AND B. Sun (2002): "An Empirical Investigation of the Spillover Effects of Advertising and Sales Promotions inUmbrella Branding," Journal of Marketing Research, 39(4), 408-420.

ERdEM, T., AND J. SWAIT (1998): “Brand equity as a signaling phenomenon,” Journal of Consumer Pyschology, 7(2), 131-157.

ERdem, T., J. SWAIT, AND J. J. LOUVIERE (2002): “The impact of brand credibility on consumer price sensitivity," International Journal of Research in Marketing, 19(1), 1-19.

ERDEM, T., AND R. S. WINER (1999): "Econometric modeling of competition: A multi-category choice-based mapping approach," Journal of Econometrics, 89, 159-175.

Erdem, T., Y. ZhaO, And A. Valenzuela (2004): "Performance of Store Brands: A CrossCountry Analysis of Consumer Store-BrandPreferences, Perceptions, and Risk," Journal of Marketing Research, 41(1), 86-100.

FARrell, J., AND P. Klemperer (2007): “Coordination and Lock-In: Competition with Switching Costs and Network Effects," in Handbook of Industrial Organization, ed. by M. Armstrong, and R. Porter, vol. 3, pp. 1967-2072. Elsevier B.V.

FrAnK, R. E. (1962): "Brand Choice as a Probability Process," The Journal of Business, 35(1), 43-56.

FudenberG, D., And J. Tirole (1984): “The Fat-Cat Effect, the Puppy-Dog Ploy, and the Lean and Hungry Look," American Economic Review Papers and Proceedings, 74(2), 361-366.

GABAIX, X., AND D. LAIBSON (2006): "Shrouded attributes, consumer myopia, and information suppression in competitive markets," Quarterly Journal of Economics.

Golder, P. N. (2000): "Historical Method in Marketing Research with New Evidence on LongTerm Market ShareStability," Journal of Marketing Research, 37(2), 156-172.

Golder, P. N., And G. J. Tellis (1993): "Pioneer Advantage: Marketing Logic or Marketing Legend?," Journal of Marketing Research, 30, 158-170.

Goldfarb, A., Q. LU, And S. Moorthy (2008): "Measuring Brand Value in an Equilibrium Framework," Marketing Science, 28(1), 69-86.

Grossman, G. M., And E. Helpman (1991): Innovation and Growth in the Global Economy. MIT Press.

Guadagni, P. M., And J. D. Little (1983): "A Logit Model of Brand Choice Calibrated on Scanner Data," Marketing Science, 2, 203-238.

Guest, L. (1955): "Brand Loyalty - Twelve Years Later," Journal of Applied Psychology, 39, 405-408.

Guest, L. (1964): "Brand Loyalty Revisited: A Twenty-Year Report," Journal of Applied Psychology, 48(2), 93-97. 
HANDEL, B. (2013a): "Adverse Selection and Switching Costs in Health Insurance Markets: When Nudging Hurts," American Economic R, 103, 2643-2682.

HANDEL, B. R. (2013b): "Adverse Selection and Inertia in Health Insurance Markets: When Nudging Hurts," The American Economic Review, 103(7), 2643-2682.

Hansen, K., And V. Singh (2015): “Choice Concentration,” UCSD working paper.

Hastings, J., A. Hortacsu, And C. Syverson (2013): "Advertising and Competition in Privatized Social Security: The Case of Mexico," National Bureau of Economic Research Working Paper 18881.

Heckman, J. J. (1981): Structural Analysis of Discrete Data and Econometric Applicationschap. Statistical Models for Discrete Panel Data. The MIT Press.

Hirose, R., R. Maia, A. Martinez, And A. Thiel (2015): "Three Myths about Growth in Consumer Packaged Goods," Discussion paper, McKinsey\&Company.

Hitsch, G. J. (2006): “An Empirical Model of Optimal Dynamic Product Launch and Exit Under Demand Uncertainty," Marketing Science, 25(1), 25-50.

HonkA, E. (2014): "Quantifying Search and Switching Costs in the U.S. Auto Insurance Industry," Rand Journal of Economics, 45, 847-884.

Hortacsu, A., And C. Syverson (2004): "Product differentiation, search costs, and competition in the mutual fund industry: A case study of S\&P 500 index funds.," The Quarterly Journal of Economics, 119(2), 403-456.

Hoyer, W. D. (1984): “An Examination of Consumer Decision Making for a Common Repeat Purchase Product,” Journal of Consumer Research, 11(3), 822-829.

Hurwitz, M. A., And R. E. CAves (1988): "Persuasion or Information? Promotion and the Shares of Brand Name and Generic Pharmaceuticals," The Journal of Law \& Economics, 31(2), 299-320.

Husband, R. W., AND J. Godfrey (1934): “An Experimental Study of Cigarette Identification,” Journal of Applied Psychology, 18, 220-223.

JEuland, A. (1979): "Brand Choice Inertia as One Aspect of the Notion of Brand Loyalty," Management Science, 25, 671-682.

Jeziorski, P., And I. Segal (2015): "What Makes Them Click: Empirical Analysis of Consumer Demand for Search Advertising," American Economic Journal: Microeconomics, 7(3), 24-53.

Jin, G. Z., AND P. LESLIE (2003): “The Effect of Information on Product Quality: Evidence from Restaurant Hygiene Grade Cards," The Quarterly Journal of Economics, 118(2), 409-451.

John, D. R., And C. A. Cole (1986): “Age Differences in Information Processing: Understanding Deficits in Young and Elderly Consumers," Journal of Consumer Research, 13(3), 297-315. 
JONES, J., AND T. LANDWEHR (1988): "Removing heterogeneity bias from logit model estimation," Marketing Science, 7, 41-59.

JudD, K. L. (1985): “Credible Spatial Preemption,” Rand Journal of Economics, 16(2), 153-166.

Kalyanaram, G., W. T. Robinson, and G. Urban (1995): "Order of Market Entry: Established Empirical Generalizations, Emerging Generalizations, and Future Research," Marketing Science, 14, 212-221.

KAmenicA, E., R. NAClerio, And A. Malani (2013): “Advertisements impact the physiological efficacy of a branded drug," Proceedings of the National Academy of Sciences.

KeAne, M. P. (1997): "Modeling Heterogeneity and State Dependence in Consumer Choice Behavior," Journal of Business \& Economic Statistics, 15(3), 310-327.

Keller, K. L. (2012): Strategic Brand Management: Building, Measuring, and Managing Brand Equity, 4th Edition. Pearson.

Kerin, R. A., P. R. Varadarajan, and R. A. Peterson (1992): "First-Mover Advantage: A Synthesis, Conceptual Framework, and Research Propositions," Journal of Marketing, 56(4), 33-52.

Kihlstrom, R. E., AND M. H. Riordan (1984): “Advertising as a Signal,” Journal of Political Economy, 92(3), 427-450.

Kim, J. B., P. Albuquerque, and B. J. Bronnenberg (2010): "Online Demand Under Limited Consumer Search," Marketing Science, 29(6), 1001-1023.

KLEMPERER, P. (1987): “The Competitiveness of Markets with Switching Costs," RAND Journal of Economics, 18(1), 138-150.

(2005): The New Palgrave: A Dictionary of Economics, second ed.chap. Switching Costs. Palgrave-Macmillan.

Koulayev, S. (2014): "Search for differentiated products: identification and estimation," Rand Journal of Economics, 45(3), 553-575.

LAmbert-PAndRaud, R., G. LAUREnt, and E. LAPERSOnNe (2005): "Repeat Purchasing of New Automobiles by Older Consumers: Empirical Evidence and Interpretations," Journal of Marketing, 69(2), 97-113.

LAMBKin, M. (1988): “Order of Entry and Performance in New Markets," Strategic Management Journal, 9, 127-140.

LAndA, R. (2006): Creating Powerful Integrated Brand Solutions. Cencage Learning.

LANE, W. (1980): "Product Differentiation in a Market with Endogenous Sequential Entry," Bell Journal of Economics, 11(1), 237-260. 
Lehmann-Grube, U. (1997): "Strategic Choice of Quality When Quality is Costly: The Persistence of the High-Quality Advantage," Rand Journal of Economics, 28(2), 372-384.

LeOne, R. P. (1995): “Generalizing What is Known about Temporal Aggregation and Advertising Carryover," Marketing Science, 14(3), G141-G150.

LiU, H., P. Chintagunta, And T. Zhu (2010): "Complementarities and the Demand for Home Broadband Internet Services," Marketing Science, 29, 701-720.

Marquardt, R. A., And A. F. MCGAnN (1975): "Does advertising communicate product quality to consumers? Some evidence from consumer reports," Journal of Advertising, 4, 27.

MAssy, W. F. (1966): “Order and Homogeneity of Family Specific Brand-Switching Processes," Journal of Marketing Research, 3(1), 48-54.

Massy, W. F., D. B. Montgomery, And D. G. Morrison (1970): Stochastic Models of Buying Behavior. MIT Press.

Matsuyama, K. (1995): "Complementarities and Cumulative Processes in Models of Monopolistic Competition,” Journal of Economic Literature, 33(2), 701-729.

McDevit, R. C. (2014): ""A" Business by Any Other Name: Firm Name Choice as a Signal of Firm Quality," Journal of Political Economy, 122(4), 909-944.

Mela, C. F., S. GuptA, And D. R. Lehmann (1997): “The Long-Term Impact of Promotion and Advertising on Consumer Brand Choice," Journal of Marketing Research, 34(2), 248-261.

Melitz, M. J. (2003): "The Impact of Trade on Intra-Industry Reallocations and Aggregate Industry Productivity," Econometrica, 71(6), 1695-1725.

Milgrom, P., And J. Roberts (1986): "Price and Advertising Signals of Product Quality," Journal of Political Economy, 94(4), 796-821.

Mittelstaedt, R. (1969): “A Dissonance Approach to Repeat Purchasing Behavior,” Journal of Marketing Research, 6(4), 444-446.

Moore, E. S., W. L. Wilkie, And R. J. Lutz (2002): "Passing the Torch: Intergenerational Influences as a Source of Brand Equity," Journal of Marketing, 66(2), 17-37.

Moorthy, S. (1988): "Product and Price Competition in a Duopoly," Marketing Science, 7(2), $141-168$. 770.

Moorthy, S., B. T. Ratchford, and D. TAlukdar (1997): “Consumer Information Search Revisited: Theory and Empirical Analysis," Journal of Consumer Research, 23(4), 263-277.

Moraga-Gonzalez, J. L., Z. SAndor, And M. R. Wildenbeest (2015): “Consumer Search and Prices in the Automobile Market," Working Paper. 
Moschis, G. P. (1985): "The Role of Family Communication in Consumer Socialization of Children and Adolescents," Journal of Consumer Research, 11(4), 898-913.

Moschis, G. P., And R. L. Moore (1979): "Decision Making Among the Young: A Socialization Perspective," Journal of Consumer Researach, 6(2), 101-112.

Muthukrishnan, A. (2015): Persistent Preferences in Market Place Choices: Brand Loyalty, Choice Inertia, and Something in Between. now Publishers, Inc.

Nelson, P. (1970): “Information and Consumer Behavior,” Journal of Political Economy, 78(2), 311-329.

(1974): “Advertising as Information,” Journal of Political Economy, 82(4), 729-754.

Osborne, M. (2008): “Consumer Learning, Switching Costs, and Heterogeneity: A Structural Examination," Economic Analysis Group Discussion Paper.

PARRY, M., AND F. M. BASS (1990): "When to Lead or Follow? It Depends," Marketing Letters, 3(1), 187-198.

Peter, J., AND J. Olson (1996): Consumer Behavior and Marketing Strategy. Irwin, 4th edn.

PICCIONE, M., AND R. SPIEGLER (2012): “Price competition under limited comparability,” Quarterly Journal of Economics.

Pollak, R. A. (1970): "Habit Formation and Dynamic Demand Functions," Journal of Political Economy, 78(4), 745-763.

PunJ, G., AND R. STAELIN (1983): “A Model of Consumer Information Search Behavior for New Automobiles," Journal of Consumer Researach, 9(4), 366-380.

RaubitscheK, R. S. (1988): "Hitting the Jackpot: Product Proliferation by Multiproduct Firm Under Uncertainty,” international Journal of Industrial Organization, 6, 469-488.

Ravn, M., S. SchmitT-Grohé, And M. URIBE (2006): “Deep Habits,” The Review of Economic Studies, 73(1), 195-218.

Reisman, D., And H. Roseborough (1955): Consumser Behavior Vol. II, The Life Cycle and Consumer Behaviorchap. Careers and Consumer Behavior. New York University Press.

Robinson, W. T. (1988): "Sources of Market Pioneer Advantages: The Case of Industrial Goods Industries," Journal of Marketing Research, 25(1), 87-94.

Robinson, W. T., And C. Fornell (1985): "Sources of Market Pioneer Advantages in Consumer Goods Industries," Journal of Marketing Research, 22(3), 305-317.

Roy, R., P. K. Chintagunta, and S. Haldar (1996): “A Framework for Investigating Habits, "The Hand of the Past," and Heterogeneity in Dynamic Brand Choice," Marketing Science, 15(3), 280-299. 
SCHERER, F. M. (1970): Industrial Market Structure and Economic Performance. Rand McNally.

Schmalensee, R. (1978): "Entry Deterrence in the Ready-to-Eat Breakfast Cereal Industry," Bell Journal of Economics, 9(2), 305-327.

(1982a): "Product Differentiation Advantages of Pioneering Brands," The American Economic Review, 72, 349-365.

Schmalensee, R. (1982b): "Product Differentiation Advantages Of Pioneering Brands," American Economic Review, 72, 349-365.

Schmalensee, R. (1983): “Advertising and Entry Deterrence: An Exploratory Model,” Journal of Political Economy, 91(4), 636-653.

SCHMitT, B. (2012): “The Consumer Psychology of Brands," Journal of Consumer Psychology, $22,7-17$.

Seetharaman, P., A. Ainslie, and P. Chintagunta (1999): "Investigating Household State Dependence Effects across Categories," Marketing Science, 36, 488-500.

Seetheraman, P. (2004): "Modeling Multiple Sources of State Dependence in Random Utility Models: A Distributed Lag Approach," Marketing Science, 23, 263-271.

SELTEN, R. (1965): "Spieltheoretische behandlung eines Oligopolmodells mit nachfrägetragheit," Zeitschrift für die Gesamte Staatswissenschaft, 121, 301-324.

Shin, S., S. MisRA, AND D. Horsky (2012): "Disentangling Preferences and Learning in Brand Choice Models," Marketing Science, 31(1), 115-137.

Shum, M. (2004): "Does Advertising Overcome Brand Loyalty? Evidence from the BreakfastCereals Market," Journal of Economics and Management Strategy, 13(2), 241-272.

Simons, H. (1948): Economic Policy for a Free Society. University of Chicago Press.

Sovinsky GoEREe, M. (2008): "Limited Information and Advertising in the U.S. Personal Computer Industry," Econometrica, 76(5), 1017-1074.

SPEnCE, M. (1976): "Product Selection, Fixed Costs, and Monopolistic Competition," The Review of Economic Studies, 43(2), 217-235.

SRINIVASAN, V. (1979): "Network Models for Estimating Brand-Specific Effects in MultiAttribute Marketing Models," Management Science, 25(1), 11-21.

Stigler, G. J. (1961): “The Economics of Information,” Journal of Political Economy, 69(3), 213-225.

Sudhir, K., AND I. TEWARI (2015): “Long Term Effects of 'Prosperity in Youth' on Consumption: Evidence from China," Cowles Foundation Discussion Paper No. 2025.

Sullivan, M. M. (1998): "How brand names affect the demand for twin automobiles," Journal of Marketing Research, 35(20, 154-65. 
Sullivan, M. W. (1992): "Brand Extensions: When to Use Them," Management Science, 38(6), 793-806.

Sutton, J. (1991): Sunk Costs and Market Structure: Price Competition, Advertising, and the Evolution of Concentration. Cambridge: MIT Press.

Tedlow, R. S. (1990): New and Improved: The Story of Mass Marketing in America. Basic Books, Inc., New York, NY.

The Nielsen Company (2014): “The State of Private Label Around the World," Discussion paper, accessed online 8/10/2016 from www.nielsen.com/us/en/insights/reports/2014/the-stateof-private-label-around-the-world.html.

Thomas, L. A. (1995): "Brand Capital and Incumbent Firms' Positions in Evolving Markets," The Review of Economics and Statistics, 77(3), 522-534.

(1996): “Advertising Sunk Costs and Credible Spatial Preemption,” Strategic Management Journal, 17(6), 481-498.

Thumin, F. J. (1962): “Identification of Cola Beverages,” Journal of Applied Psychology, 46(5), 358-60.

Tuchman, A. E., H. S. Nair, and P. M. Gardete (2015): “Complementarities in Consumption and the Consumer Demand for Advertising," Working Paper.

Urban, G. L., T. Carter, S. Gaskin, and Z. Mucha (1986): "Market Share Rewards to Pioneering Brands: An Empirical Analysis and Strategic Implications," Management Science, 32(6), 645-659.

VAn Osselaer, S. M. J. (2008): Handbook of Consumer Psychologychap. Associative Learning and Consumer Decisions, pp. 699-729. Erlbaum.

WARD, S. (1974): “Consumer Socialization,” Journal of Consumer Research, 1(2), 1-14.

Weitzman, M. L. (1979): “Optimal Search for the Best Alternative,” Econometrica, 47(3), 641654.

WERnERFELT, B. (1988): "Umbrella Branding as a Signal of New Product Quality: An Example of Signalling by Posting a Bond," The RAND Journal of Economics, 19(3), 458-466.

Wolinsky, A. (1987): "Brand Names and Price Discrimination," The Journal of Industrial Economics, 35(3), 255-268.

Zettelmeyer, F. (1995): “The Strategic Use of Consumer Search Cos,” Ph.D. Thesis, Sloan School of Business, MIT. 
Table 1: Description of Brand Sales and Shares

\begin{tabular}{lccccc}
\hline Concentration & Obs & Mean & Std. Dev, & Min & Max \\
\hline Equivalent Units & $14,494,228$ & 470755 & 3740882 & 0.01 & 827000000 \\
Equivalent Units Share & $14,494,228$ & 0.26 & 0.25 & 0.00 & 1.00 \\
Dollar Sales & $14,494,228$ & 47369 & 163987 & 0.00 & 20800000 \\
Dollar Sales Share & $14,494,228$ & 0.27 & 0.25 & 0.00 & 1.00 \\
Number of Brands & $14,494,228$ & 240 & 464 & 1 & 7467
\end{tabular}

Notes; Equivalent units are used to ensure that brand sales in a category are measured in comparable units (e.g. ML for beverages, OZ for foods, counts for sachets etc).

Table 2: Category Concentration (by Category and Market)

\begin{tabular}{cccccc}
\hline Concentration & Obs & Mean & Std. Dev, & Min & Max \\
\hline C1 & 80,636 & 0.46 & 0.24 & 0.03 & 1 \\
C2 & 80,636 & 0.65 & 0.24 & 0.06 & 1 \\
C3 & 80,636 & 0.74 & 0.22 & 0.08 & 1 \\
C4 & 80,636 & 0.79 & 0.20 & 0.10 & 1
\end{tabular}

Notes: $\mathrm{C} 1, \mathrm{C} 2, \mathrm{C} 3$ and $\mathrm{C} 4$ represent the one, two, three and four-firm concentration ratios respectively. Sales within a category are measured using equivalent units (e.g. ML for beverages, $\mathrm{OZ}$ for foods, counts for sachets etc). Concentration is measured using the sample equivalent unit sales for a category (i.e. total across time within a market).

Table 3: Analysis of Variance of Top Two CPG Brand Shares by Category

\begin{tabular}{lccccc}
\hline Variable & Obs & Mean & Std. Dev, & Min & Max \\
\hline Market & 1,069 & 0.18 & 0.17 & 0.00 & 0.95 \\
Brand & 1,069 & 0.33 & 0.32 & 0.00 & 1.00 \\
Month & 1,069 & 0.11 & 0.14 & 0.00 & 0.82 \\
Market $\times$ Brand & 1,069 & 0.68 & 0.26 & 0.00 & 1.00 \\
\hline \multicolumn{4}{c}{ Notes: R-square values correspond to a category-specific analysis. }
\end{tabular}

Table 4: Analysis of Variance of Top Two CPG Brand Shares by Department

\begin{tabular}{lcccc}
\hline Department & Market & Brand & Month & Market $\times$ Brand \\
\hline ALCOHOLIC BEVERAGES & 0.25 & 0.22 & 0.05 & 0.77 \\
DAIRY & 0.31 & 0.31 & 0.09 & 0.77 \\
DELI & 0.42 & 0.19 & 0.06 & 0.79 \\
DRY GROCERY & 0.21 & 0.35 & 0.07 & 0.77 \\
FRESH PRODUCE & 0.20 & 0.12 & 0.13 & 0.49 \\
FROZEN FOODS & 0.28 & 0.23 & 0.09 & 0.69 \\
GENERAL MERCHANDISE & 0.09 & 0.27 & 0.20 & 0.46 \\
HEALTH \& BEAUTY CARE & 0.09 & 0.41 & 0.20 & 0.58 \\
NON-FOOD GROCERY & 0.13 & 0.38 & 0.11 & 0.68 \\
PACKAGED MEAT & 0.28 & 0.32 & 0.03 & 0.82 \\
\hline \multicolumn{4}{c}{ Notes: Mean R-square value across all Categories within a Department. }
\end{tabular}


Figure 1: The joint geographic distribution of share levels and early entry across U.S. markets in ground coffee (source: Bronnenberg, Dhar, and Dubé, 2009).
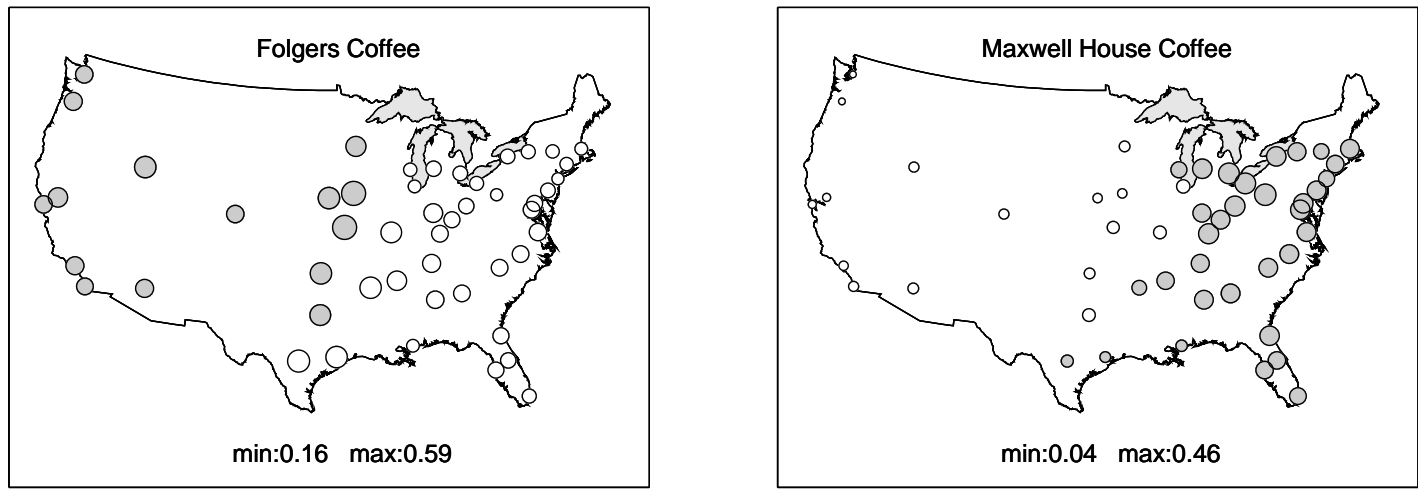

The areas of the circles are proportional to share levels. Shaded circles indicate that a brand locally moved first. 